\title{
The Relationship between the Main Gods of EI-Baharyah Province and the Goddess Neith during the Late Period
}

\author{
Mofida Hassan El-Weshahy Samar Mohammed Mosleh \\ Tour Guidance Department \\ Faculty of Tourism and Hotels, Suez Canal University
}

\begin{abstract}
:
Traditionally conceived as the creator of all deities, the goddess Neith played an important role in the ancient Egyptian religion. She held a number of different features, such as the fierce goddess of war, symbol of lightning, patron of weaving, inundation and protector of the deceased's body. Many objects of the Late Period - found at the ancient sites of the Bahyreh province - reveal the religious aspects of the goddess Neith in the Western side of the Bolbitine Branch. This research proves that the goddess Neith was the main goddess of the Western Delta, especially the land lying between the Bolbotine and Canopic Branches of the Nile. The goddess Neith gained the greatest prominence by the $26^{\text {th }}$ dynasty's pharaohs, particularly at their capital Sais in the Western side of the Delta. There, she became the state deity of Egypt down to the $30^{\text {th }}$ dynasty and Ptolemaic Period. Neith was very deep-rooted goddess connected with the Delta.
\end{abstract}

Keywords: Goddess, Neith, Baharyah, relationship, Late Period

\section{Introduction}

The Ancient Egyptian site of El-Baharyah province included many ancient Egyptian lower nomes: the $2^{\text {nd }}$ letopolite nome $i w a$; the $3^{\text {rd }}$ Libyan nome imntt (rmp); the $4^{\text {th }}$ Prosopite nome Nit-rsyt (aha); the $5^{\text {th }}$ saite nome Nit-mhjt (wrh); and the $7^{\text {th }}$ Metelite nome hwi imntt (ntry irw, wr rc, smsw). ${ }^{1}$ The $2^{\text {nd }}$ lower Egyptian nome xm or $i w a^{2}$ lied at the point where the route leading to Wadi Nantrum approaches the Rosetta branch of the Nile; there lies the town of Kom Abu Billo Terenuthis, ${ }^{3}$ The name is derived from serpent goddess rnnt, its temple was dedicated to the goddess Hathor, "Lady of turquoise" pr Ht. Hr nbt nfkAt. Burials of cattle, found there in vicinity, are probably connected with the cult of Hathor. ${ }^{4}$ In the New Kingdom and the Late Period the temple was associated with the goddess-Sekhmet which, was known as pr sxmt nbt $n$ HsAt, or pr sxmt nbt r HsAt, which means the house of Sekhmet "Lady of terror" or "The house of Sekhmet (the lioness), mistress of fierce regard". 5

The principal city of the $3^{\text {rd }}$ lower Egyptian nome, imntt "the western", in the middle and New Kingdoms was iAmw (Kom El Hisn كوم الحصن), which replaced the earlier site Ht-iHjt "the house of the cow iHt", which was associated with the goddess Neith. Its principal city in the Late and Greco-Roman Periods was Damanhur "dmi $n \mathrm{Hr}$ " the town of Horus, ${ }^{8}$ which was known as Hermopolis Parva "the small town of DHwtf". Its ancient temple was dedicated to the goddess Sekhmet-Hathor. ${ }^{10}$ The southern part of the $4^{\text {th }}$ lower Egyptian name nt-rsjt, the southern Neithy, included Naukratis (Kom Gief, El-Niberia and Niqrash). ${ }^{11}$ The Ancient Egyptian temple of Naukratis was dedicated to the gods Amon and Thoth. This is in addition to several Greek temples for Apollo, Aphrodite and Zeus. ${ }^{\text {I2 }}$ This part connected with the goddess "Neith". Meanwhile, some parts of the $7^{\text {th }}$ lower Egyptian nome, which was known as Metelite Hwi imntj, $R^{a}$-imnty, the western Ra), gs-imnty (the western side), ${ }^{13}$ included Mareotis (now Kom Idress) whose principal city was known as Hermopolis Parva (dmi $n \mathrm{Hr}$ ) in the late and Greco-Roman Period. ${ }^{14}$ This is in addition to $R^{a}$-imnty, which probably specified "Atum", the son of the goddess "Neith", as the evening sun. During the Late Period, these western provinces of the Delta were settled by Libyans who were known to the Greek as "Machinoi"m i.e. the warriors. ${ }^{15}$ Pasmatik I caused that the Greeks and Cariens to settle in the western side of Bolbitine Branch of the Nile (fig. 1), while at the time of Amasis, they became powerful and their activities were apparent in the city of Naukratis. ${ }^{16}$

The Goddess "Neith" gained the greatest prominence by the $26^{\text {th }}$ Dynasty's pharaohs at their capital Sais $s A w$ in the western side of the Delta and she became a state deity of Egypt down to the $30^{\text {th }}$ Dynasty and Ptolemaic Period. ${ }^{17}$ Neith was very deep-rooted goddess connected with the Delta. ${ }^{18}$ She was of lower Egyptian origin, ${ }^{19}$ and her symbol represents two bows tied together in a package, a shield with two crossed arrows and crossed arrows upon a divine standard. ${ }^{20}$ Her symbol was found in the tomb of the $1^{\text {st }}$ Dynasty at Saqqara and Abydos where several Queens bore her name, ${ }^{21}$ whereas her symbol was also depicted upon her head, ${ }^{22}$ or the red crown symbol of the Delta in the same time. ${ }^{23}$ She was venerated also in the guise of a beetle (since Neith was represented or inhabited a beetle). ${ }^{24}$

\section{Neith: the Creator of All Deities}

The Goddess Neith occupied important role in the Egyptian pantheon; she held a number of different features, and was the fierce goddess of war and hunting. Besides, she was the symbol of lightning, patron of weaving, inundation and protector of the deceased's body. ${ }^{25}$ Neith was identified as "'mother of all", who created the seed of gods and mem. ${ }^{26}$ 
She was bisexually male and female, ${ }^{27}$ mother of the mothers and father of the fathers. ${ }^{28}$ Neith also created the world, ${ }^{29}$ and Egypt by the utterance of "aha.n b3k.n.s" ${ }^{30}$ A text inscribed in a Naophoraus statue of the priest of Neith $w D A H r$ rsi nit (Vatican Mas. No. 196) identified her as "mother who gives birth to $\mathrm{R}^{\mathrm{c}}$ and who was the insatiate of birth after there had been no birth", ${ }^{31}$ as well as the monuments of sais "Nit wrt $m w t \quad n T r \quad m s(w) \quad R a "$

"Neith the great one, mother of the god, who gives birth to $\mathrm{Ra}^{(32)}$, and $\mathrm{Esna}^{(33)}$, so she was associated with Isis, Mut, Seshat, Menhet, Tawrt, Hathor, Skhemet, Bastet and Renunt. ${ }^{34}$ Neith was also associated with Arisnoe I in the Greco-Roman Period. ${ }^{35}$ She was introduced into a national cult where she was regarded as identical Palas, Athena and Minerva. ${ }^{36}$ Neith emerged from chaos on the primeval hill (at Sais and Esna) and her mouth pronounced the seven names which fashioned the world khnum, Ra, Amon, the eight, Thoth, Apophis and Esna, Sais. ${ }^{37}$ She was represented giving suck two crocodiles (Osiris and Ra) ${ }^{38}$ or (shu and Tefnut). ${ }^{39}$ It is the powerful and wise "Neith" to whom the other deities turn for guidance "... put Horus in the place of his father...". ${ }^{40}$

\section{Neith in the Western Side of the Bolbitine Branch}

Many objects of the late Period was found at the Ancient sites of the Bahyreh province. They reveal the religious aspects of the goddess "Neith" as the following documents show:

Doc. 1: A block depicted the king of Psmatik II $n f r$ ib Ra (Beautiful is the heart of Ra) in front of cow and bullheaded gods perhaps the goddess Neith and the bull Apis, it was found at Rosetta. ${ }^{41}$

Doc. 2: A block dates back to Pasmatik II ( $n f r$ ib Ra) with the goddess Neith, Atum and Horus. ${ }^{42}$

Doc. 3: Blocks of the King Apris who venerated "Neith" was found at Rossetta. Dr. Labib Habachi believed that they came from Apris's building at Sais connected with the goddess Neith. ${ }^{43}$ Perhaps there was a temple dedicated to the goddess Neith on the mouth of Bolbitine Branch of the Nile under the last native dynasties between "Canapic mouth" or "Heracleion mouth" and "Bolbitine Branch" or "Naukratis mouth". It might be at Thonis, about which Hirodotus tells. ${ }^{44}$ Such a relief refers to the relationship between the goddess "Neith" and "Atum". The creator god of Heliopolis who emerged from the chaos, and who came into existence by himself, ${ }^{45}$ as did the goddess Neith (at Sais and Esna), while Neith here was the creator of "Atum" in the form of $R a{ }^{46}$ as her son "... he will be khepri in the dawn and Atum in the evening ...". ${ }^{47}$ Atum had a special shrine in the temple of Neith at Sais where he was the representation of the god $\mathrm{Ra}$ in the west, ${ }^{48}$ and the female term of "Atum" "itmt" connected also with the cow goddess ${ }^{49}$ (NeithMeyther and Hathor). A stela from Sais depicted the King Tefnakht giving offerings in front of the goddess "Neith" and "Atum". 50

Doc. 4: A Quartzite hollow base for sacred hippopotamus not a sarcophagus, with a text referring to the King Pasmatik II ( $n f r$ ib Ra) now in Cairo Museum and was found at Demanhur. ${ }^{51}$ Neith was represented as a hippopotamus, especially in the seven $T s w$ utterances of the goddess Neith at Esna. She transferred herself to hippopotamus wrrt as aHa.n wHm.n.s. ${ }^{52}$ At Fayoum, she was represented as a hippopotamus, hanging down her terrify, the skin of a crocodile as a remembrance of her traditional fight or as her son, ${ }^{53}$ for she was called "Nt wrt sA.s xnt axm w.s Hr S" that means: "Neith the great one, her protection is in front of her (images) on the Fayoum lake (fig. 2). ${ }^{54}$ In the ruins of the city of Kerkeosiris was found a strange monument of Ptolemaic Period which reveals the crocodile Sobek on one base with the baboon Thoth and the hippopotamus in the middle between them. ${ }^{55}$ She might be the goddess Neith with her son Sobek and Thoth representing the triad of Kerkeosiris, while at Kom Ombo the hippopotamus depicted the motherhood as the goddess Ipt, Neith, Hathor, Nut, Ta- snt-nfrt, Ta- wrt, Hjdt and Mut. ${ }^{56}$

Doc. 5: The Birth name of King Amasis and its relation with the goddess "Neith" (iah $m s$ sA Nit) (the moon birth or the moon is born, the son of the goddess Neith) which is represented on a sphinx perhaps from Sais. A naos found on the sea shore near Alexandria and stela found near Mariout lake. ${ }^{57}$ At Naukraties appeared the last cylindrical sign of Egypt (fig. 3.6), the scrab (fig. 3.1), ${ }^{58}$ Menat (nTr nfr hum ib Ra sA Ra iaH ms sA Nit anH Dt) (fig. 3.5), 59 "The good god, the heart of Ra, the god Khnum, the son of Ra, the moon birth, son of Neith, may he live forever", and the usual foundation plaques which bear his name (fig. 3.2,3,4). ${ }^{60}$ The Nbtj name of king Amasis is also

connected with the goddess Neith iah ms sA Nit spd tAwy lands".

Doc. 6: A black granite naos now at Cairo Museum CG.70020, dedicated to the goddess Neith by the king Nektanebo I ( $n x t n b . f)$ (fig. 4). ${ }^{62}$. It is $63 \mathrm{~cm}$ high, and was found at Demanhur. The Naos was made of one block with a rounded top which was inscribed in the middle with the hieroglyphic sign (di anH wAs), "may he give life and power", a winged sun disk ( $b H d t n \operatorname{Tr} a A$ ), "Horus Bhdty the great god".

The text on the right side of the naos is inscribed with ( Hr TmA aA-niswt bitj xpr kA Ra-sA Ra nxt nb.f-mry Nit wrt mwt nTr), "the Horus name strong arm - the king of lower and upper Egypt, the soul of Ra Abides - the son of Ra strong of his lord, ${ }^{63}$ beloved of Neith the great one the mother of the god". The text on the left side had the same titular of king Nektanebo I: "... mrj $n$ Nit nbt At $x t$ ", "beloved of Neith, mistress of At $x t$ ", which means the primeval hill 
at Sais that is associated with the goddess Neith. Daressy says that this place might be chapel of Osiris at Sais in the north. ${ }^{64}$ This is not right, however, because the chapel of Osiris at Sais was named (Ht bitj). ${ }^{65}$ Osiris also had a great relationship with Naophoraus statues at Sais, ${ }^{66}$ and was considered the child of goddess Neith. ${ }^{67}$ The rounded-top of the naos represented the ancient shrine of Neith's temple at lower Egypt, ${ }^{68}$ which was represented on the Naophoraus statues of Sais on $26^{\text {th }}$ Dyn to $30^{\text {th }}$ Dyn. ${ }^{69}$ It may be associated with the heaven dome which gives truth to the stars. ${ }^{70}$ the facade with its rounded top might be an imitation of the stelae. Neith also the goddess who put every god on his naos. ${ }^{71}$

\section{Doc 7: Naukratis stela of Nektanebo I, Cairo Museum JE.34002, (fig. 5). ${ }^{72}$}

Some wonderful sculptures were erected during the king Nektanebo I's great era in the $30^{\text {th }}$ Dynasty. the Naukratis stela is one of the examples that show the application of hardstone relief to sculpture in the round. The rounded-top stela is dedicated to the goddess Neith, mistress of Sais. It is decorated in sunk relief with beautiful image of the goddess Neith. Found at Naukratis, the stela dates back to the $1^{\text {st }}$ year of king Nektanebo I's reign, and it recorded the gift of the goddess Neith of a tithe of all imports from Greek, tithe of all production of Naukratis, made grants and land tax remissions to the goddess Neith. The style of $30^{\text {th }}$ Dynasty indicates a fine work in the round, the sky "pt" round, as the rounded-top of the stela and a winged sun disk can be seen. It includes much decoration: two Uraeus are hanging from the sun disk wearing the white and red crowns of Upper and Lower Egypt. These may represent the goddess "Nit-rsjt and Nit-mHjt", and titular of Nektanebo I (see Doc. 6). The relief of the goddess is extremely well done, reflecting a fine scene of composition and balance. The figure of the goddess is represented with ample bosom, slim waist and beautiful face. The scene is divided into two sections, on the left side the king wears the red crown of lower Egypt offering a tray of bread, beer and water, and facing the seated goddess Neith who is clad in the red crown and holds the " $w A s "$ scepter and life sign, while in the right side the king is wearing the "Atf" crown, offering the "wsxt" pectoral to his mother Neith. The iconography of the king copies the representation of the king Pasmatik II in the Western Delta. ${ }^{73}$ Below the scene is a $14^{\text {th }}$ vertical columns of hieroglyphic inscriptions running from right to left, it shows that the king goes forth from his house, while approaching the temple of the goddess Neith, entering the temple and wearing the red crown of his mother Neith. ${ }^{74}$ The $10^{\text {th }}$ columns indicates the nome $p r$ - $m r j t$, the $3^{\text {rd }}$ lower Egyptian nome including mrjt (Mareia), Ht- Wsir (Taposiris), Ht- Hapi and $h t$ - cAt (Libya)?, ${ }^{75}$ and the name of Naukratis nw $\mathrm{kArt},{ }^{76}$ which may mean the power of the sea or the village of crew. ${ }^{77}$ Nektanebo decree stipulated that a tax equivalent to $10 \%$ of the taxes collected as offering to the temple of " Neith " is meaning the stela of Nektanebo I that was established at Naukratis not Sais. A temple of the goddess Neith was erected in that district.

Doc. 8: Stela of Nektanebo I from Heracleion No. 277. (fig. 6 ). ${ }^{78}$ It is an intact greywacke stela, $197 \mathrm{~cm}$ high and $88 \mathrm{~cm}$ wide, announcing the decision taken by Nektanebo I in November $380 \mathrm{BC}$. on behalf the temple of Neith at Sais. This stela is the perfect double of the so-called Naukratis stela (see Doc. 7); both had the same material, same dimensions and quality of engraving, as well as the same double representation showing the Pharaoh in the presence of the goddess " Neith ". Both stelae also share the the same legends accompanying the images, the same text over $14^{\text {th }}$ columns with the most five minor graphic varieties and only one different piece of phrasing. Two versions of the same documents were discovered on the site of the two towns to which related to a large destroy in the course of time. The stela of Heracleion recorded ... $r w A D w r m$ Haw $n b w \ldots$ "... at the mouth of the sea of the Greek in the city" named Thonis of Sais ". ${ }^{79}$ J. Yoyotte has suggested that this refers to the Egyptian role and that both Thonis and Heracleion were in fact one place. ${ }^{80}$

Doc. 9: A decorated slab with Egyptian cornice at BM. 998. The way in which it was represented on BM. 20, 22, Bologna 1870, shows that the figure had been intentionally damaged. Found at Rosetta, only his head remains. Its dimensions are $4 \times 2$ feet. It represents the king Nektanebo I, wearing the kushite tight cape with the uraeus, ${ }^{81}$ offering a necklace consisting of small beads in front of the goddess "Neith". The scene shows the naturalistic portrait-type which was known from the relieves of Lower Egypt and was a replica of a slab of Pasmatik II found in Rosetta. ${ }^{81}$

Doc. 10: Head of Wen-nefer "servant of Neith", is now at Baltimore Museum No. 51257.(fig. 7). ${ }^{83}$ Its back pillar provided a quite valuable date. It may refer to the fact that it came from Western Delta, especially the firth of the Canopic Branch. The damaged trapezoidal shape of the pillar represents a bull with a sun disk facing right, and standing on the base line of the trapezoid. On the right, there was probably a figure of the statue's owner, worshiping the sacred animal. The upper part is inscribed with the main text which is missing now, and it shows Wn-nfr titles "servant of Neith", "Revered by Hapi-skr-Osiris the great god of Shethyt". So the bull is representing the Apis-Bull of Western Delta must have had a temple of the firth of the Canopic Branch which housed an extraordinary image of Hapi the god of the Nile. ${ }^{84}$ This head refers to the relationship between "Neith" and "Hapi" in Western Delta, "Neith" was known as the daughter of Hapi and other texts associated her with "Hapi" as inundation deities, ${ }^{85}$ another text from a late statue CG. 427 refers to the shrine of Hapi at Sais which was called Agb. ${ }^{86}$ 
"... In the great place, servant of the god "priest" of $3 \mathrm{gb}$ in the abod of $3 \mathrm{gb} ",{ }^{(87)}$ Neith was also bisexual, ${ }^{88}$ and the mythological daily bath of the sun was performed by Njt rsjt (Neith of the north) and Njt rsjt (Neith of the south), where she was in the form of the primeval water. ${ }^{\left({ }^{2}\right)}$

Doc. 11: A kneeling figure of lime stone with inscriptions on the front, the back pillar and the base is showing the name and the title of servant of goddess Neith called Pasmatik-Snb. He was connected with the rebuilding of the temple of Neith. Sir W.F. Petrie bought this statue in Cairo, but afterwards it is said that it came from Kom Afrin, ${ }^{90}$ south west of Naukratis, located on the western boundary' of the Delta.

Doc. 12: The priest of Athena at Naukratis, where Herodotus identified the divinities of Egypt with those of Greece. ${ }^{91}$ Such identification became much more general and complete in later years when they were masters in Egypt. In Naukratis itself, excavation has revealed the remains of the early temple of Hera, Apollo and Aphrodite. ${ }^{92}$ I. Noshy suggested that the Greek associated "Athena" with "Neith" and the statue of Aphrodite at Sais should have been dedicated for the goddess "Neith', ${ }^{93)}$ not for the goddess Hathor. ${ }^{94}$ It also associated her with Hera. ${ }^{95}$ The priest of Athena at Naukratis had an additional "Law orders" syngraphophylax". ${ }^{96}$ Neith also was known as "Hermaphroadite", as she had taken the functions of Herms and Aphrodite. ${ }^{97}$

\section{Neith and the deities of the Western Delta}

\section{A: Neith and Horus}

The Western Delta was a cult-center of Horus "bHdtj" and Tholh at the Hermopolis parvas. ${ }^{98}$ However. "Hr-nfr" Horus, the good one, might be the son of Thoth and Nehmetawy. ${ }^{99}$ Neith was also identified as the "mother of Horus", 100 while the latter was called "the son of Neith" "Hr sA Nit", "Horus in houses of Neith" "Hr m Htw Nit" at Sais. ${ }^{101}$ A bronze statue, inlaid with gold, represented Neith standing behind her two children. The taller of them, who wears the double crown, was "Horus the child" and the other one wearing the red crown was "Horus of the Delta " (fig. 8). ${ }^{102}$ Horus was

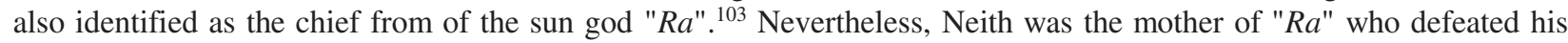
enemies. ${ }^{104}$ She was depicted with Horus the child. ${ }^{105}$ Many small figures, found outside the great Temenos of Naukratis, were connected with the god Horus, as pottery and bronze hawks, sacred eyes " $w D A t$ " and Isis protected her son Horus with her wings. ${ }^{106}$ The most delicate representation is of a figure worshipping a hawk-headed crocodile with the sun disk and the Uraeus. ${ }^{107}$ It must be a representation of Horus-Sobek, and glazed pottery of Horus made from the style of Egyptian prototypes. It was found in the southern temple of Apollo, ${ }^{108}$ who was associated with the god Horus. ${ }^{109}$ An important object from Kom Afrim is connected with the god "Ra-Horakhty" as a falcon headed god, a bronze figure of a sacred bark of "Ra", inlaid with deep ribs of gold. The face and the disk above it were of plain bronze, while the Uraous on the head, the whole wig, and the collar were inlaid (fig. 9). ${ }^{110}$ The Cartouche is inscribed with the throne name of Amasis, "khnm ib $R a$ " "the lord of the two lands". ${ }^{111}$ There were a great relationship between Horns and Thoth, where the latter filled and wounded the eye of Horus. ${ }^{112}$ In the Greek civilization, Apollo was associated with Hermes. ${ }^{113}$

\section{B: Neith and Thoth}

Neith was the mother of Thoth at Baklja. She was associated with Thoth at Sais. She created Thoth and Apophis after $R a$ at Esna, ${ }^{114}$ and declared herself saying" ..... I am $n b t w . . .$. I am Thoth the heart of Ra". ${ }^{115}$ Ibis was the chief sacred animal of Thoth and was connected with the Delta. ${ }^{116}$ Herodotus gives many interesting details concerning the Ibis bird in the Delta and how he destroyed the winged serpents that were brought into Egypt by the west wind ${ }^{117}$ It must give Thoth an important role in protecting the western side of the Delta in the late Period. On the seashore near Abu Quir was found a large Catacomb of Abis mummies "Hb-wsir". ${ }^{118}$ The Kadoussi jars had no writing or paint but it indicates the fact that the god Thoth was widely worshipped on the firth of the Canopic Branch of the Nile (fig. 10). ${ }^{119}$ Here, Thoth was associated with "Hapi" and Serapis. ${ }^{120}$ Thoth also was the chief god of "pr-anx" "house of life" of the temple of the goddess Neith at Sais during the new kingdom and the Late Period. ${ }^{121}$ many objects were found in the district concerning the god Thoth "son of Neith".

a. A black granite libation-dish of commander of troops " $w D A H r$ rsj $n t^{\prime \prime}$ Dynasty. $26^{\text {th }}$ (fig. 11). ${ }^{122}$ It was found

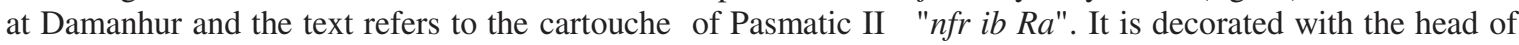
the goddess Hathor as his wife. ${ }^{123}$

b. The obelisk of Nektanebo II might be from Hermopolis Parva (Damanhûr). It is now one of a pair in BM. They have been erected originally before Thoth temple in one of the Delta cities, it had Nektanebo II's titles " $\mathrm{Hr} n b w$ smn Hpw niswt bity, snD m ib-Ra mrj InHrt, sA Ra, nxt Hr Hb anx mi Ra, mry DHwty aAwj nb xmnw nb mdw $n T r$ xnt Hsrt", 124 "the golden Horus "smn hpw", "king of lower and upper Egypt", pleasing to the heart of "Ra" beloved of Anhor, (strong is the feast of Horus) may live like "Ra", beloved of Thoth, lord of Ashmonin, lord of the divine word in front of "Hsrt". This place was associated with Osiris at Hermopolis. ${ }^{125}$ The obelisk is of fine one black of basalt and of good quality, its pyramidion was already missing when the French found the monuments (fig.12). ${ }^{126}$ Nektanebu II's small objects indicated to his religious aspects, under the protection of 
the god, especially Neith of Sais as "nht Hr hbt sA Nit" Neith". ${ }^{127}$

c. At the southern part of Naukratis was an Egyptian temple dedicated to Amun and Thoth, but nothing of such monuments can be seen nowadays. ${ }^{128}$ Some small stone objects were found, bearing the name of Thoth (fig. 13). ${ }^{129}$ Also a small glazed potteries of Thoth and a ram's head were found. ${ }^{130}$ The two gods were associated with the Dioskouroi (Castor and Pollux) in the Greco-Roman Period. ${ }^{131}$

d. The limestone stela of Damanhur, Cairo Museum CG.22188, a decree passed at campus by general council of the Egyptian priests of Ptolemy III for the temple of Canop, ${ }^{132}$ and the Rosetta stone of Ptolemy V, Epiphans, which was discovered at Rashid by Napoleon's expedition in $1799 .{ }^{133}$ Both stelae copied the decree of canopus. They consist of the $19^{\text {th }}$ lines of Hieroglyphic text in particular for the sacred Apis and mentioned the gods Thoth and Amon. ${ }^{124}$ At Heracleion also was a temple of "Amon of the gereb" as the king of the gods in the famous decree of canopus. ${ }^{135}$ Amon had great relationship with goddess Neith, while at Esna he was the ancient Amon who is in the primeval water. ${ }^{136}$ At Armant, Amon himself was represented as a crocodile. ${ }^{137}$

\section{C: Mut and Neith}

Identified as goddess Mut, ${ }^{138}$ Neith had a shrine on the temple of Neith at Sais, ${ }^{139}$ where Mut was the mistress of "Nit$r s j f^{\prime \prime}$ Fragments of the goddess Mut (maybe Hathor or Isis) were found at Damanhûr, ${ }^{141}$ and sculptured at the end of $30^{\text {th }}$ Dynasty. It depicted the goddess Mut seating, wearing the goddess Nekhbet-headdress which was engraved with many details (fig. 14). ${ }^{142}$ The goddess holds the " $w A D "$ scepter of lioness goddess that represent Lower Egypt. ${ }^{143}$ The relief show that she was young, her mouth is slightly smiling, her nose defiant, and her checks full and sensual with a beautiful and gentle profile.

\section{D: Neith and Sekhmet}

Neith was associated with goddess Sekhmet, ${ }^{144}$ because they both were goddesses of war and Sekhmet had a great ability of healing and magic at the temple of Neith at Sais. ${ }^{145}$ In the region, the temple of Sekhmet-Hathor was built by middle kingdom's kings, King Ramsess II and King Schashanq III. ${ }^{46}$ Sekhmet was also related to the Western Desert. According to the myth of the book of the gate, Sekhmet created the fair-skinned Libyan then Thoth created the languages to separate races. ${ }^{147}$ Nefrtum, the son of goddess Sekhmet, was buried at Memphis as an Ibis-bird who was the sacred animal of Thoth. ${ }^{\mathrm{I} 8}$ Many amulets, small statuettes of Nefrtum, ${ }^{149}$ Menat of Sekhmet (fig. 15), ${ }^{150}$ lion and lion's head were also found at Naukratis.

a- A tablet from Kom Afrim dedicated to the goddess Sekhmet. The significance of this is her title "nbt iA $m w "$ "lady of Kom El Hisn". ${ }^{152}$

b- A perfume bottle in the form of a hedgehog, made of faience $6.8 \mathrm{~cm}$, in a style commonly called Naukratite (fig. 16-a). ${ }^{153}$ Also associated with Mut, were Bes and Sekhmet, At temple of Kharga Oasis, however, she was depicted as a hedgehog (fig. 16-b). ${ }^{154}$

\section{E: Neith and the cow goddess}

The goddess Neith was associated with the cow-goddess Mehyt.wrt "MHt-wrt, iHt (fig. 17), Sdf"155 Hathor "Ht-Hr". 156 Methyer too was a form of Neith. ${ }^{157}$ In the seven "Tsw" uttrance of Methyer at Esna, Neith transformed into "iHt" and "MHt-wrt"158 as a primordial deity, a personification of the female, a solar deity, an agriculture deity and a goddess of moisture. ${ }^{159}$ The ancient name of "iAmw " kom el Hisn was "Ht-iHt "the temple of the cow godess $i H t$ ", ${ }^{160}$ who was associated with Neith and Hathor, was called "lady of $i A m w "$ and had a shrine in the temple of Neith at Sais. She

illumined the west. ${ }^{161}$ Neith was also associated with the holy tree of Neith, "the acacia of Neith",${ }^{162}$ and Hathor was worshipped at Memphis with the name of Methyer. ${ }^{163}$ In the southern city of Naukratis, the Egyptian town, the temple of Aphrodite was established by the Greek in 688 BC. She was identified as the goddess Hathor and Neith. ${ }^{164}$

\section{F: Neith and Sobek}

Sobek (the crocodile and the crocodile headed-god) was the son of Neith in pyr. text 510 (wnjs) ${ }^{165}$ he was identified as the eldest son of Methyer at Fayoum, ${ }^{166}$ the secret of the cow "IHt", ${ }^{167}$ and the crocodile god "SmA-nfr", who was the son of Neith at Esna. ${ }^{168}$ Sobek was established as a local deity in the western Delta names:

a) He was "nb iw-nfr" in the lower Egyptian $5^{\text {th }}$ nome. ${ }^{169}$

b) Sobek was "sbk $m H t$-nbwt" a locality Metelite nome (lower Egypt $7^{\text {th }}$ nome). ${ }^{\text {I70 }}$

c) Sobek was "Sobek, lord of the west" "sbk nb.imtt" in the lower Egyptian $3^{\text {rd }}$ nome. ${ }^{171}$

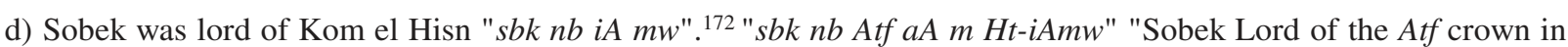
the temple of Kom el Hisn - Greek Memphis. ${ }^{173}$ 
e) Sobek was "Sobek in the temple of the cow goddess $i H t$ " sbk $m$ Ht-iHyt" may be Gynaecopolis. ${ }^{174}$

f) Sobek was "the lord of the $4^{\text {th }}$ lower Egyptian nome "Nit-rsjt". ${ }^{175}$

He was also worshipped at the firth of the Canopic Branch of the Nile. Sobek was also connected with the Nile god "Hapi" as inundation deities. ${ }^{176}$ A limestone statuette of Sobek as crocodile mummy is now in Cairo Museum. It

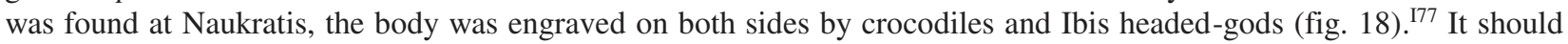
indicate the relationship between Sobek and Thoth, the moon-gods at Western Delta as it did at Fayoum. ${ }^{178}$

\section{G: Neith and Osiris}

Neith was not only the mother of crocodiles Sobek, Shema-nfr, Ra, Horus but also was the mother of Osiris where she was sucking him as a crocodile at Esna and the temple of Queen Hatshipswt at Buhen. ${ }^{179}$ Neith united with Osiris in the form of "Nit-wsir", ${ }^{180}$ as she did with Ra, while at Sais her cult was connected with the god Osiris in "Ht-bity". ${ }^{181}$ Many amulets and small statuettes were found at Naukratis. ${ }^{182}$ The recent underwater excavations which had been carried out in Abu Quir bay discovered a bronze statue of Osiris, ${ }^{183}$ and a bronze figure from Itay El-Baroud, east of Naukratis now at Ashmolean Museum No. 1888.166. It represents the moon god "wsir iaH" with lunar disc and crested on his head, seated and holding the flail and the crook. There is an Uraeus on the forehead (fig. 19). ${ }^{184}$

\section{Conclusion}

The research proves that the goddess Neith was the main goddess of the Western Delta especially the land lying between the Bolbotine and Canopic Branches of the Nile down to the Roman era where a bronze helmet crest was found at Heracleion (Abu Quir bay). It was believed to be part of a $4.5 \mathrm{~m}$ high of Greek Statue of Minerva (fig. 20). ${ }^{185}$ This figure was a representation of the Roman war goddess Minerva, the Egyptian Neith "lady of the sea", standing at the gateway to her domain in Thonis of Sais.

- The seven provinces of Western Delta which was depicted on the so-called Libyan Palette represent the conquered seven towns and/or show the foundation of seven cities of the Western Delta. ${ }^{186}$ It dates back to King Menes. ${ }^{187}$ It must be referring to the seven utterance of Neith as a creator goddess of all western lower Egyptian nomes not only Sais.

- The previous documents indicated that there might be many temples of goddess Neith at Damanhûr, Naukratis, Bolbitie, Heraclioen, Thonis, Canop and Alexandria, where a temple for the goddess Mehyt-wrt (Neith) was erected. It was called Methyerioem at the Serapioum of Alexandria in the time of Alexander the Great, ${ }^{188}$ as she was " the lady of the sea". ${ }^{189}$

- Neith was thought of to have had a Libyan Origin, ${ }^{190}$ but it was not true because she was an archaic deity, represented the Delta. The actual subject is that Neith was venerated by the foreigners especially who settled in western Delta from the $10^{\text {th }}$ century BC and the temple of Neith at Sais had increased its translators class. ${ }^{191}$ She was also a local goddess of some frontier district of Egypt claiming rule over the adjacent foreign land over Libya and western Delta. ${ }^{192}$

- Neith was an Egyptian deity that was connected with the desert as a "lady of the desert". ${ }^{193}$ She was associated with ghosts and smoke people. ${ }^{194}$

\section{References}

1) Cauville, Ś., Dendera, Les Chapelles Osiriennes, IFAO, 117 (1997), p. 11, 110; EL-Sayed, R., La Deesse Neith De Saïs, I, DdE 86 (1982), p. 39.

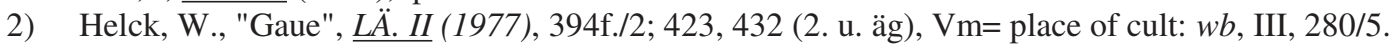

3) Malék, J., Baines, J., Atlas of Ancient Egypt (New York, 1992), p. 168.

عبد الحليم نور الدين ، مواقع ومتاحف الآثار الدصرية، القاهرة، 991 (192، صـ0، 00، عبد الحليم نور الدين، مواقع الآثار اليونانية الرومانية في

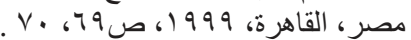

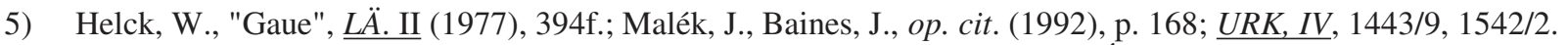

6) Helck, W., op. cit. (1977), 394/3,423, 422(3. u. äg); André Bernard, Delta Égyptien I, M1FAO (Cairo, 1970), p. 571.

7) Jacquet-Gardon, H., Les Noms Des Domaines Funéraires dans L'Ancien Empire Égyptien, BdE 34 (1962), pp. $311,392,402,417$.

8) Tahia Shehab El-Din, The Terms "Village" and "Town" in Ancient Egypt and its conformity with the modern Egyptian concept, $A S A E, 76,2001$, p. 175.

9) Helck, W., $\underline{\text { L̈II }}$ (1977), 395f., André Bernard, op. cit. (1970), p. 30, 55; Habachi, L.,"Damanhur", $\underline{\underline{L A} I}$ (1975), 988, 989f.;

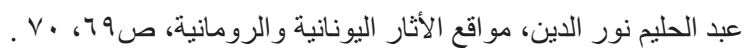

10) Malék, J., Baines, J., op. cit. (1992), p. 168 (Kom El-Hisn); Saker, F., "Excavation at Kom El-Hisn, Al-Ensanait”, Journal of Faculty of Arts Alexandria University, Damanhour Branch, Vol. 11 (2002), p. 15, 16. 
11) Helck, W., "Gaue", L̈̈. II (1977), 396/4; 423, 424 (4- 5- äg); Lurker, M., Göiter undSymbol der Allen Ägypter, Die Mythische Welt des Pharaonemeich (1991), 96f ; El-Sayed, R.? BdE 86-1 (1982), p. 39, Doc. 235.

12) Malék, J., Baines, J., op. cit. (1992), p. 169; Petrie, W. F., Gardiner, E., Naukratis 1 (London, 1885), pp. 1.

13) Helck, W., LÄ. II (1977), 396/7, 424, 423 (7. u. äg); Jacquet-Gardon, H., op. cit. (1962), p. 393.

14) Helck, W., L̈̈. II (1977), 396, $397 \mathrm{f}$.

15) Gardiner, A., Egypt of The Pharaohs (New York, 1961), p. 356;

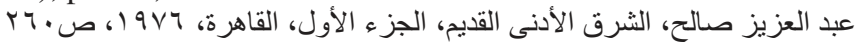

16) Grimal, N., Histoire De L'Egypte Ancienne(1993), p. 456, 457, 468; Gardiner, A., op. cit. (1961), p. 362; Peter A. Clayton, Chronicle of The Pharaohs (London, 1994), p. 197;

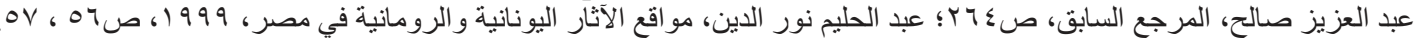

17) Grimal, N., op. cit. (1993), p. 455, 456, 484;

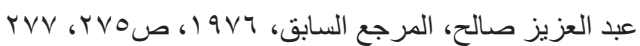

18) El-Sayed, R., La Déesse Neith De Saïs, I, BdE 86 (1982), p. 44, II, pi. I - Doc. I, 2, 26, Černý, J., Ancient Egyptian Religion (1982), p. 27; Brovaski, E., "Two Writing Boards", ASAE 71 (1987), p. 35.

19) Kees, H. referred to Neith's Libyan origin, see: Kees, H., Ancient Egypt, A Cultural Topography (Chicago and London, 1961), p. 185.

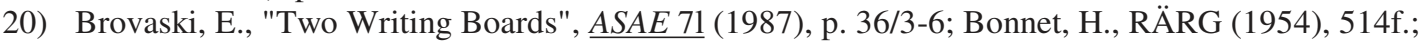

21) Gardiner, A., op. cit. (Oxford, 1961), p. 411,412, fig. 16; Emry, W. B., Archaic Egypt (1991), figs. 8, 28, 29; Brovaski, E.,ASAE 71 (1987), p. 35, 36/10; El-Sayed, R., op. cit., Tom. 11 (1982), pl. I-Doc. 71, pl. III-Doc. 108.

22) Schlichting, R., "Neith"; L̈̈. IV (1982), 392ff., Černý, J., op. cit. (1957), p. 27, 29; Daumas, F., Valevrs Phonetiques Des Signcs Hieroglyphiques D'Epoque Gréco-Romain, Institut D'Egyptologie Unversite Paul-Valéry (Montpellier, 1995), p. 664, 665.

24) Brovaski, E., ASAE 71 (1987), p. 36; El-Sayed, R., op. cit., Tom. II (1982), pi. II- Doc. 74;

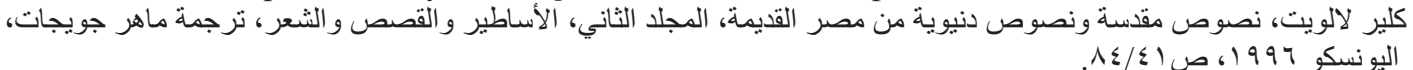

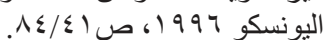

25) Schlichting, R., "Neith"; L̈̈. IV (1982), 392f.; Lurker, M. Göiter und Symbol der alten Ägypter, Die Mythische Welt des Pharaonenreich (1991), 183f.; Černý, J., op. cit. (1957), p. 27; Faulkner, R. O., Ancient Egyptian Pyramid Texts (Oxford, 1969), p. 118 (362), pyr. 606; Brovaski, E., ASAE 71 (1987), p. 35; Spence, L., Ancient Egyptian Myths and Legends (1990), p. 21; El-Sayed, R., op. cit., II (1982), pi. XV-Doc. 1094,1, p. 81:85;

26) Simon, C, "Neith", The Oxford Encyclopedia of Ancient Egypt, Vol. II (2001),p. 516;

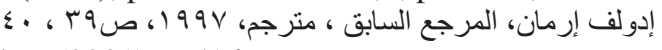

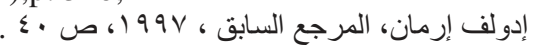

27) (2/3 male and 1/3 female), see: r كلير لالوليت، المرجع السابق، اليونسكو 997 ; lurker, M. op. cit. (1991), 182f., Horrtung, E., Tal Der könige, Die Ruhestatte Der Pharaonen (1995), 81/5f., El-sayed, R., op.cit. I (1982), p. 58, $59 \& 12$.

28) Ménassa, L., Le Temple D'Esna (IV-2), IFAO (Le Caire,1975), pl. XI (No. 424-2);

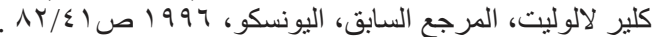

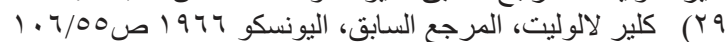

30) Broze, M., "Le Sept Porpos Des Méhyt, Structure Narrative et Théorie du Savoir dans la Cosmognie de Neith a Esna", BIFAO 99 (1999), p. 64, \& 6 , Tableau 1 (b3k= Egypt).

31) Gardiner, A., op. cit. (1961), p. 366; Gardiner, N., op. cit. (1993),p. 474, 475; Posner, G. La Premiére Domination Perse en Égypte (Le Caire, 1936), p. 7: 16.

32) El-Sayed, R., op. cit., II (1982), pi. V- Doc. 434, pi. X- Doc. 657; Thiers, Ch., Ptolémée Philadelphe et les Prêtress des Sais, "La Stèle Codex Urinianus, fol. 6 ${ }^{\text {re }}$, Naples 1034, Louvre C.133", B1FAO 99 (1999), p. 424, col. 1-c, fig. 1; Meulenare, De H., BIFAO 87 (1987), BM. 178, p. 135, 140, pl. XXI;

$$
\text { إدولف إرمان، المرجع السابق ، مترجم، القاهرة، و99 19، ص • ؟ . }
$$

33) Sauneron, S., Le Temple D 'Esna, V (1962), p. 255a, 268-269;

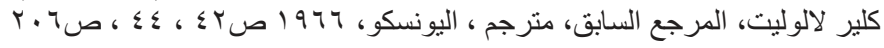

34) Ménasse, L., Le Temple D 'Esna (Le Caire, 1975), pl. XII, 424/1;

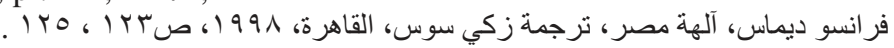

35) Thiers, Ch., "Ptolémée Philadelphe et les Prêtress des Sais", BIFAO 99 (1999), p. 440, fig. 2, 424.

36) Yoyotte, J., "Guardian of The Nile: Thonis Rediscovered" reports on the recent dramatic discovery of Heraclein made of Egypt by Frank Goddio of the Institut Européen D'Archéologie Sous-Marine (IEASM), MINERVA, Vol. 13-Number 3 (2002), p. 32; Schmidt, V., Chois Monuments Égyptiens, Deuxiéme Serie (1918), p. 63, fig. 149.

37) Sauneron, S., Esna, V, Le Fétes Religieuses, p. 268, 269; Koenig, Y., Le Contre-Envoûtement de Ta-i-Di-Imen, BIFAO 99 (1999),p. 271/89;

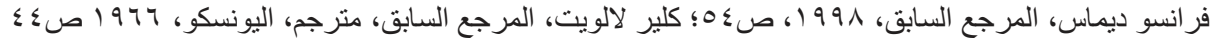

38) El-Sayed, R., op. cit., 11 (1982), pl. X- Doc. 644; Davies, N. de G., The Temple of Hibis at Kharga Oasis (1953), pl. 5;

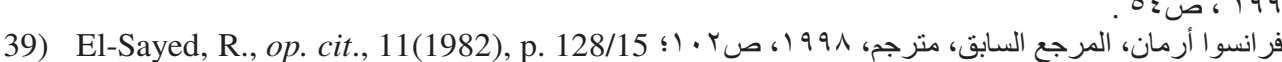


Simon, C, "Neith", The Oxford Encyclopedia of Ancient Egypt, Vol. II (2001), p. 516; Meeks, D., Meeks, Ch. F., La Vie Quqtidienne des Dieux Égyptiens (Hachatte, 1993), p. 166.

41) PM, The Lower and Middle Egypt, Vol. IV (1934), p. 1.

42) Peter A. Clyton, Chronicle of The Pharaohs (London, 1994), p. 195; Andrew, C, La Pirre de Rosette, British Museum (1994),p. 8, fig. 2; Wiedemann, Agyptische Geschichte, 634f.; Habachi, L., ASAE, XLII (1942), p. 372.

43) Gauthier, H., Le Livre Des Rois D 'Égypte, Tom. IV (916),p. 109, XVIa, XVII, a, b.

44) Yoyotte, J., MINERVA, Vol. 13/3 (2002), p. 32.

45) Černý, J., Ancient Egyptian religion (London, 1957), p. 43; El-Sayed, R., op. cit. I (1982), Doc. 509, 467b., p. $124 / 9 /$

46) Broze, M., "Le Sept Porpos Des Méthyer", BIFAO 99 (1999), p. 69;

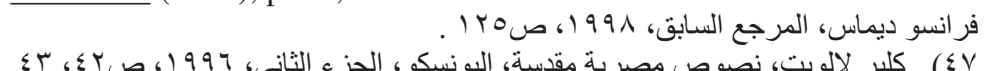

48) Posner, G., La Premiére Domenation Perse En Égypte (Le Caire, 1936), p. 2.

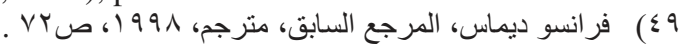

50) El-Sayed, R., Documents Relatives a Sais Et Ses Divintes, BdE 69 (1975), p. 38, 39, pi. VII, Doc. 3, Musèe D'Athènes; El-Sayed, R., op. cit., BdE 86 (1982), I, p. 467b, p. 124.

51) PM, Lower and Middle Egypte, IV (1934), p. 49; Maspero, G., "Notes sur Quelques Points de Grammaire et D'Histoire, $\underline{Z A ̈} Y_{Y}$, p. 79; Gauthier, H., Le Livre des Rois, IV (1916), p. 97/2

52) Broze, M., "Les Sept Propos des Méthyer", BIFAO 99 (1999), p. 64, 20, tableau 1; El-Sayed, R., op. cit. I(1982),p. $658 / 4$.

53) Koenig, Y., op. cit., BIFAO 99 (1999), p. 268 (wr.t); EI-Sayed,R., op. cit., II (1982), pl. XI, Doc. 714.

54) Lanzone, R. V., Les Papyrus du Lac Moreis (Turin, 1896), Tav. V.

55) Brovarski, E., "Sobek", $\underline{\operatorname{LA} V}(1984), 1014 / 373$.

56) Morgan, De J., Ombos 1 (1895), N. 32, 44; 49.

57) Peter A. Clayton, op. cit. (London, 1994), p. 194; Beckerath, J. Von, "Königsnamen", L̈̈ III (1980), 555f./ Dyn. 26-5; Beckerath, J. Von, Handbuch des Ägyptischen Königsnamen, MÄS 20 (1984), 112, 113 f.; Petrie, W. M. F., Tell-Defenneh (London, 1887), p. 110, pi. XLI, 76; Gauthier, H. M., Le Livre des Rois, IV (1916), p. 113 (I stela), 115. V, 118 XXI, 119 XXIII, XXIV, 121, 122 XXXIX, 123 (XLV-B Naos), 124-XLVIII (sphinx), 125, $126,127$. 128.

58) Petrie, W. M. F., Scarabs and Cylinders (London, 1917), pi. VI, 26.5.4.2; Petrie, W. M. F., Historical Scarabs (London, 1914), XXVI-63, BM. 1991.

59) Petrie, W. M. F., op. cit. (London, 1917), pi. LVI.26.5.5; Gauthier, H. M., Le Livre des Rois, IV (1916), p. 127 (LXV1I).

60) Petrie, W. M. F.,op.cit (1917), pi. LVI.26.5.3; Petrie, W. M. F., op. cit (1914), pi. 63, Nos. 1992, $1993,1994,1995$.

61) Gauthier, H. M., LR VI (1916),p. 118, 120, 121; Beckerath, J. Von, L̈̈ III (1980), 555f.

62) PM, Lower and Middle Egypte, IV (1934), p. 49; Roeder, G., Naos, Câtalogue Géneral des Musée du Caire (1914), p. 57, 58, pl. XVI; Gauthier, H. M., LR VI (I916),p. 189 XXI; El-Sayed, R., op. cit., I (1982), Doc. 404, p. 420

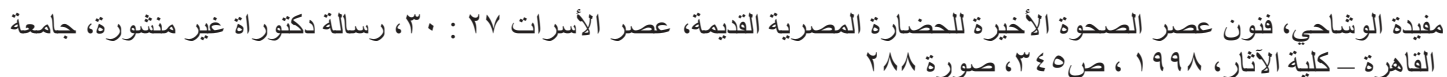

63) Peter A. Clayton, op. cit. (London, 1994), p. 203; Beckerath, J. Von, "Königsnamen", L्̈̈̈ III (1980), 555f./ Dyn. 30-1; Beckerath, J. Von, Handbuch des Ägyptischen Königsnamen, MÄS 20 (1984), 116f.; Gauthier, H. M., Le Livre des Rois, IV (1916), pp. 183.

64) Daressy, M. G., "Remarques et Notes", Rec. Trav. XI, p. 80,81, XXII.

65) El-Sayed, R, op. cit., BdE 69 (1975), Doc. 8, pl. XV, XVI, p. 110, 111, 114, 115; El-Sayed, R., "Deux Aspects Nouveaux du Culte À Sais", BIFAO 76 (1976), p. 96; Naville, E., Mound of Jew and The City of Onias, The Antiquities of Tell El-Yahûd eh (London, 1890), pl. XVI-No. 23.

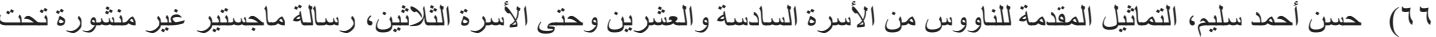

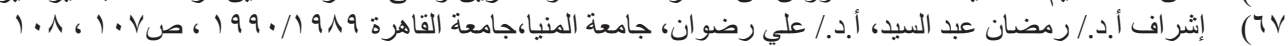

El-Sayed, R., op. cit., I (1982), p. 117.

69) Lurker, M., Götter und Symbol (1991), 182f.; pr nw = Wb, I, 517 (5); El-Sayed, R., La Déesse Neith, BdE 8886/11 (1982), pi. 1, Doc. 73, pi. II, Doc. 114.

70) Bothmer, Von B., Egyptian Sculpture of the Late Period (1960), No. 72, fig. 174, p. 89,90; El-Sayed, R., op. cit, $\underline{B d E 69}$ (1975), Doc. 2, pl. Ill, 4, p. 29, 34.

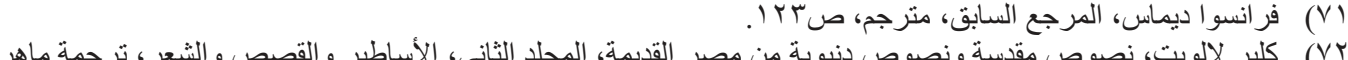

$$
\begin{aligned}
& \text { (VT }
\end{aligned}
$$

74) Erman, A., "Die Naukratis Stelle", Z̈̈S 39, 12ff.; Maspero, G., Guide des Musèe du Caire (1914), pl. IX; PM IV (1934), p. 50; Wilcken, U., "Die Naukratis Stelle", Z̋̈S 38 (1900), 130ff.; Gauthier, H. M., LRVI (1916),p. 184 (II); El-Sayed, R., op. cit., 1 (1982), p. 416: 418, Doc. 481; 
75) Mysliwiec, K., Royal Portraiture of the Dynasties XXI: XXX(1988), p. 79, pi. LXXIX, a, b, d.

76) El-Sayed, R., La Déesse Neith des Sais, BdE 86/2 (1982), p. 417, 418, Doc. 481.

77) Karl W. Butzer, "Mareoties", L̈̈ III (1980), 189ff.

78) PM IV (1934), p. 50; Petrie, W. M. F., Gardiner, E., Naukratis, 1(1886), pp. 1; Meulenare, De H., "Naukratis", $\underline{L A}$ IV (1982),

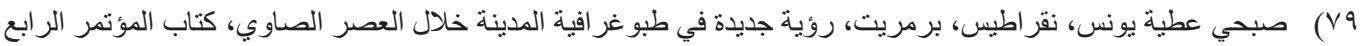

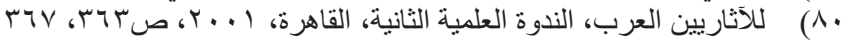

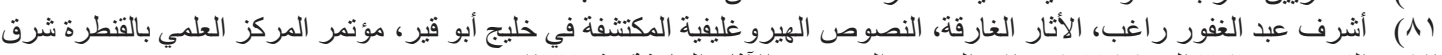

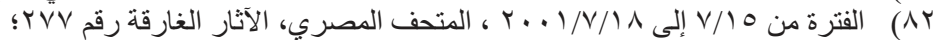

Yoyotte, J., op. cit., MINERVA, Vol. 13/3 (2002), p. 32, fig. 1,4.

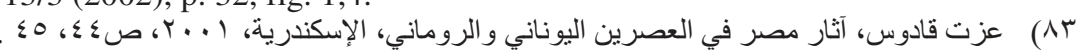

84) Yoyotte, J., op. cit., MINERVA, Vol. 13/3 (2002), p. 34.

85) Budge, W. A., Guide to the Egyptian Galleries Sculpture, p. 50; Arundal-Bonomi, Gallery of Antiquities, pl. 145, fig. 165, p. 110, 111; Bothmer, B. Von, Egyptian Sculpture of the Late Period, 700 BC to 100 AD (1960), p. 91.

86) Mysliwiec, K., Royal Portraiture (1988), p. 79, pl. LXXXVI, a, b.

87) Bothmer, B. Von, op. cit. (1960), p. 98, 99, No. 78, pi. 75, fig. 195, 196.

88) Yoyotte, J., op. cit., MINERVA, Vol. 13/3 (2002), p. 33, fig. 2; Bonneau, D., La Crue du Nile Etudes et Commentaires 52 (Paris, 1964), p. 221c (Apis). 243 (Osiris).

89) El-Saycd, R., "Deux Aspects Nauveaux du Culte A Sais", BIFAO 76 (1976), p. 100, 95;

90) El-Sayed, R., op. cit., I (1982), p. 128/15, Doc. 1114; Budge, E. W., op. cit., BdE (1989),p. 496 (hapj Hr ib sAw); Kurth, D., "Nilgott", $\underline{\operatorname{LA} I V}(1982)$, 487f. (footnote 1), pyr. 1173.

91) El-Sayed, R., BIFAO 76 (1976), p. 95, 96, pi. XVII (CG. 427); El-Sayed, R., op. cit., I (1982), p. 129, Doc. 564 .

92) Lurker, M. Göiter und Symbol (1991), 199f.; Sauneron.S., Esna, III, p. 263, 265; El-Sayed, R., op. cit., (1982), p. 58. 59.

93) Vernus, P., Lessing, E., The Gods of Ancient Egypt (1998), p. 118, 188.

94) Petrie, W. F., Gardiner, E, Naukratis I (1886), p. 94, pi. XXXVI-1.A.B.C; El-Sayed, R., op. cit, li (1982), p. 467 and also Doc. 498, Doc. 507.

95) Spence, L., Ancient Egyptian Myths and Legends (New York, 1990), p. 303; Cerny, J., Ancient Egyptian Religion (London, 1957), p. 134. 92

96) Černý, J., op.cit (1957), p. 134.

$$
\begin{aligned}
& \text { (9V }
\end{aligned}
$$

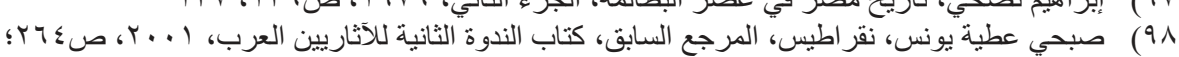

Gardiner, E., Naukratis II (London, 1888), p. 55, pl. XIV, XV.

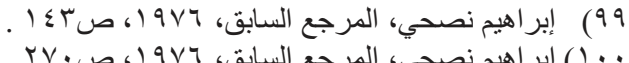

101) Broze, M, "Le Sept Propos des Méthyer", BIFAO 99 (1999), p. 71; Tardieu, M., Trois Mythes Gnostiques (Paris, 1974), p. 116.

102) Schenkel, W., "Horus", $\underline{L A ̈ I I I}$ (1980), 19f.; Andree Bernand, op. cit. (1970), p. 55; Habachi, L., "Damanhûr", $\underline{L A} I$ (1975), 988f.; Homung, H., Tal der Könige (1995), Abb. 8.

103) Baylan, P., Thoth, The Herms of Egypt (Oxford, 1992), p. 209 (n. I), Zivie, A-P: Herrnopolis et Nome de L'Ibis, I, BdE 66 (1975), p. 138, Bonnet, H., RÄRG (1952), 518f.; Vernus, P., Lessing, E., op. cit. (1998), p. 62, 63;

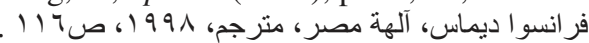

104) El-Sayed, r., op. cit.,BIFAO 76 (1976), p. 95, 105,106; El-Sayed, R., op. cit, BdE 69(1975), Doc. 5 (Stele Dyn. 26), El-Sayed, R., op. cit., I (1982), p. 49;

105) El-Sayed, R., op. cit., I (1982), p. 113, Doc. 468, 498a, b.

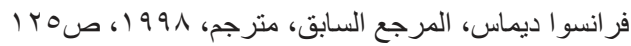

106) Egyptian Illustration of the Louver Museum, (1992), p. 170-A; El-Sayed, R., op. cit, II (1982), pi. VII, Doc. 424, 472, Doc. $636=$ CG.39378.

107) Schenlel, W., "Horus", L्̈̈ III (1980), 14f; Spence, L., op. cit. (1990), p. 85; Vernus, P., Lessing, E., op. cit. (1998), p. 74

108) Posner, G., op. cit. (1936), p. 2, 7; Gardiner, A., op. cit. (1961), p. 366, 367;

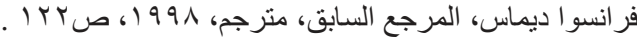

109) Simon, C, "Neith", The Oxford Encyclopedia, Vol. II (2001),p. 516; El-Sayed, R., op. cit. II (1982), pi. XII, Doc. 1000.

110) Petrie, W. F., Gardiner, E., Smith, C, Naukratis I (1886), p. 38, 41, 42;

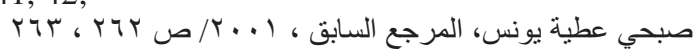

111) Petrie, W. F., Gardiner, E., op. cit., I (1886), p. 38, 41, No. 174; Milne, J. E., Journal of Helfenic-Studies 21, (1901), 277f.; Brovarski, E., "Sobek", L̈̈ IV (1982), 1051 f.; El-Sayed, R., op. cit., I (1982), Doc. 481, $483,610$.

112) Petrie, W. F.,op.cit, I (1886), p. 38, 42.

113) Spence, L., op. cit. (1990), p. 181; Černý, J., op. cit. (1957), p. 135.

114) Petrie, W. F., Gardiner, E., op. cit., I (1886), p. 95, pl. XII; PM, IV (1934), p. 51.

115) Peter A. Clyton, op. cit. (1994), p. 195. 
116) Meeks, D., Meek, Ch. F., op.cit. (Hachette, 1993), p. 66; Gwyn Griffiths, J., The Conflict of Horus and Seth (Liverpool, 1960), p. 28/41; Spanel, L., op. cit. (1990), 127.

117) Bowmann, A., Egypt After The Pharaohs (1986), p. 172; Paul-Louis Van Berg, "Hérmès et Agni", Religions Méditerranéennes et Orientates de L 'Antiquité (1999), p. 212, 213.

118) El-Sayed, R., op. cit., I (1982), p. 48, Doc. 469, 609, 888; Broze, M., "Le Sept Propos des Methyér", $\underline{B I F A O ~} 99$ (1999), p. 67 (tableau 2); Sauneron, S., Le Temple D'Esna, IFAO 5 (1962), p. 255a;

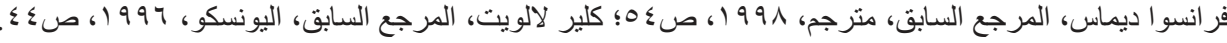

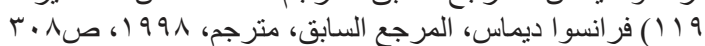

120) Zivie Alian, p., Hermopolis et L 'Norn D 'Ibis (1975), 11 f.; Zivie Alian, P., "Ibis". L̈̈̈ III (1980), 117f.; Bleeker, C. J., Hathor and Thoth, SHR 26 (Leiden, 1937), p. 108, 109.

121) Ray, D. Jhon, The Oxford Encyclopedia, Vol. 1 (2001), p. 346; Spanel, L., op. cit. (1990), p. 296.

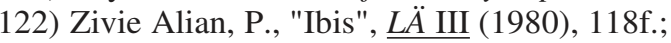

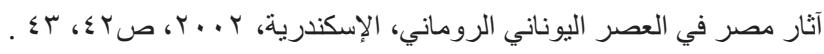

123) Abdul-Quader, M., "Serapeum of Alexandria", ASAE 56 (1987), p. 122, 123 (or a shrine on "Serapis" or "Oracle Temple" at Abu-Quir), see: Thissen, H.-J., "Kanopus", L्Ä III (1980), $320 \mathrm{f}$.

124) Benneau, D., La Crue Du Nile, Etudes et Commentaires 52 (Paris, 1964), p. 319 (Serapis), p. 234 (Thoth).

125) Gardiner, A., op. cit. (1960), p. 296;

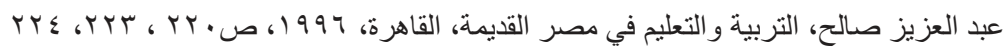

126) PM, IV (1934), p. 49; Robert Anderson, Fawzy, I., Egypt Revealed Scenes from Napoleon's Description de L 'Egypte (1987), Vol. V, pi. 74= Syndney, H., Description de L 'Egypte Publiee sous les Oreders de Napoleon Bonaparte, Vol. V (1993), pi. 74.

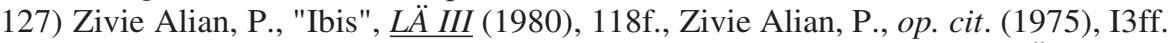

128) Peter A. Clyton, op. cit. (1994), p. 203; Beckerath, J. Von, op. cit., MÄS 20 (1984), 116, H7f.; Gauthier, H., LRIV (1916), p. 178-XXX.

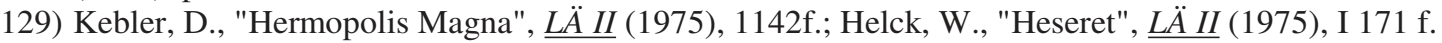

130) Robert, A., Fawzy, I, op. cit., Vol. V (19878), pl. 21, 22.

131) Gauthier, H. M., LR IV (1916), p. 178, XXXII= British Museum No. 2793; El-Sayed, R., op. cit., I (1982), p. 237, 287; II, p. 403, 417, 614.

132) Malek, J, Banies, J., Atlas of Ancient Egypt (1992), p. 168, 169.

133) Petrie, W. F., Gardiner, E., Naukratis, I (1886), pl. XX-4.

134) Petrie, W. F., Ibid (1886), pp. 43, 42, 37.

135) Olaf E. Kaper, Klaos A. Worp, "Dipinte on the Temenes Wall at Deir El-Haggar", BIFAO 99 (1999), p. 233, figs. 7, 8, 12, 14, 18, 18; Bowmann, A., Egypt After The Pharohs (1986), p. 171.

136) PM, IV (1934), p. 50; Kamal,A., Stèles Ptolémaiques et L' Inscription Romaines, Câtalogue Géneral des Musée du Caire (1905, 6), pls. LXII, LXIII, p. 183, 184; Bowmann, A., op. cit. (1986), p. 26; Thissen, H. -J., "Kanopus", $\underline{L A}$ III (1980), 32If.

137) Andrews, A., op. cit. (1994), p. 12, 13; Bowmann, A., op. cit., p. 30, 170.

138) Andrews, A., Ibid (1994), p. 26.

139) Yoyotte, J., MINERVA, Vol. 13/3 (2002), p. 34.

140) Broze, M., op. cit., BIFAO 99 (1999), p. 71.

141) Brovarski, E, "Sobek", LA IV (1982), 1012f; El-Sayed, R., op. cit., II (1982), Doc. 610-a.

142) Sauneron, S., La Porte Ptolémaïque de L'Enciente de Mut À Karnak, IFAO (1983), pl. XII, 13, XVII; Armor, A. R., Gods and Myths of Ancient Egypt (1995), p. 93; El-Sayed, R., La Déese Neith de Sais, BdE 86/11 (1982), p. 436, Doc. 474, Col. 8, p. 139, 140/30,I, Doc. 424, pl. VII.

143) El-Sayed, R., Ibid (1982), p. 139, 140.

144) El-Sayed, R., Ibid (1982), p. 577, Doc. 919.

145) PM, IV (1934), p. 49 (Damanhûr).

146) Syndney, H., op. cit., Vol. V (1993), pl. 73 (13), 13.

147) Graham, G., "Insignias", The Oxford Encyclopedia of Ancient Egypt, Vol. II (2001), p. 166, fig. 20.

148) El-Sayed, R., op. cit., BdE 69 (1975), Doc. 2, pl. Ill, IV (Statue du Louvre E. 25980,p. 29; El-Sayed, R., op. cit., I (1982), p.; 136,1, Doc. 1054.

149) El-Sayed, R., Ibid (1982), p.34; Josephson, J. A., El-Damary, M. M., , Catalogue General of Egyptian Antiquities in Cairo Museum (1999), pl. II, a, b,p. 24, "wab priest of Sekhmet at Sais"; Budge, E. W., The Mummy (1989), p. 372;

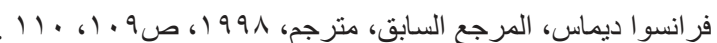

150) Saker, F., El-Ensaniat, Vol. 12 (2002), p. 15, 16; Petrie, W. F., Naukratis, I (1886), p. 94, 95; Gauthier, Le Livre des Rois, Tom. Ill (1916), p. 366-XXII; PM, IV (1934), p. 51;

151) Armour, R. A., Gods and Myths of Ancient Egypt (1995), p. 93.

152) James, T. G. H., A Short History of Ancient Egypt (1995), p. 151, BM.67149.

153) Petrie, W. F., Gardiner, E., Naukratis, I (1886), p. 42.

154) Petrie, W. F., Ibid (1886), pl. XX-8.

155) Petrie, W. F., Ibid (1886), p. 37. 
156) Petrie, W. F., Ibid (1886), p. 94, pl. XXXV1-2.

157) James, T. G. H., op. cit. (Cairo, 1995), p. 75; Petrie, W. F., Naukratis, I (1886), p. 37; Cairo Museum J E. 30742.

158) Davies, N. de G., The Temple of Hibis at Kharga Oasis, III (1953), pl. 5-IV.

159) El-Sayed, R., op. cit., BdE 86/11 (1982), pl. X, Doc. 644; El-Sayed, R., "Un Document Relatif au Culte dans Le Fayoum", BIFAO 81 (1981), p. 320; El-Sayed, R., op. cit., I (1982), Doc. 72; El-Sayed,R., BIFAO 79 (1079), p. 100; Homung, E., Geist Der Pharaonenzeit (1993), 35f.;

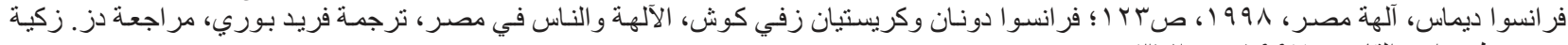

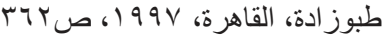

160) Budge, A. E. W., The Mummy (1989), p. 372; Davies, N. de G, Hibis (1953), pl. 3-VI, 13; El-Sayed, R., op. cit, I (1982), p. 142, n. 37.

161) Hornung, E., Der Eine und Die Vielen (1971), Abb. 3; Faulkner, R. O., The Ancient Egyptian Pyramid Texts (Oxford, 1969), p. 99, pyr. 507 a, c; Lanzone, R. V., Les Papyrus du Lac Moreis (Turin, 1896), Tav. VI (XXX), II (IX), I (II); El-Sayed, R., op. cit., I (1982), p. 51: 56;

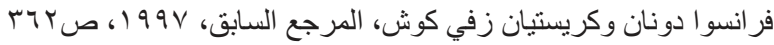

162) Broze, M., "Les Sept Propos des Méthyer", BIFAO 99 (1999), p. 67, tableau 2.

163) Spence, L., op. cit. (I990), p. 163, 169.

164) Malek, J., op. cit. (I992), p. 168.

165) El-Sayed, R., "Au Sujet De La Statue CaireCG.662, BIFAO 11 (1977), p. 105: 107; Spence, L., op. cit. (1990), p. 164.

166) Kuentz, C, "Quelques Monuments du Culte de Sobek", $\underline{B I F A O 28}$ (1929), p. 158; El-Sayed, R., op. cit., $\underline{B d E ~ 86 / 1}$, p. 28, 29, Doc. 519, 507, 704.

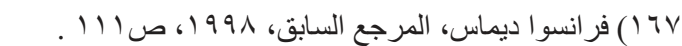

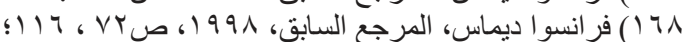
Spence, L., op. cit. (1990), p. 168, 181; El-Sayed, R., op. cit., I (1982), p. 142.

169) El-Sayed, R., Ibid (1982), Doc. 197, p. 101: 103, pl. XV-Doc. 1017; El-Weshahy, M., "Representation of Crocodile-God inside the Sun-disk at Fayoum", The Second Conference of the Faculty of Archaeology, Cairo University, Al-Fayoum Branch (Fayoum, 2002), p. 43, Reference 35.

170) Lanzone, R. V., op. cit. (Turin, 1896), Tav. VI; El-Sayed, R., op. cit., 1 (1982), Doc. 72, p. 52.

171) Lanzone, R. V., Ibid (1896), Tav. IV; El-Sayed, R., BIFAO 81 ( 1981), p. 322, 317.

172) Sauneron, S., "Esna",L̈̈ II (1975), 3If.

173) Habachi, L., $\underline{A S A E} 42$ (1942), p. 388.

174) Brovarski, E., "Sobek_“ $\underline{L A} I V(1982), 1009-b$. f.

175) Brovarski, E., Ibid, 1017-c. f.

176) Ibid, 1017-d. f.

177) Kuentz, C, B1FAO 2S ( 1929), p. 158, 159.

178) Brovarski, E., op. cit. (1982), 1017-e. f.

179) Brovarski, E., Ibid. (1982), 1017-f. f.; Lanzone, R. V., op. cit. (Turin, 1896), Tav. 6, p. 57.

180) Bonrveau, D., La Crue du Nile, Etudes el Commentates 52 (Paris, 1964), p. 243; Kurth, D., "Nilgoth", LÄ IV (1982), 487C; El-Sayed, R., DIFAO 81 (1981), p. 322; El-Weshahy, M., op. cit. (Fayoum, 2002), p. 49, fig. 7; Leibovitch, L., JNES XII (1953), p. 108.

181) Wild, H., Qasr-Qarfin, "Dionysais", Fauilles-Franco-Swisses Rapports, II, "A Petit Tableau se Rapportant an Culte de Sobek, IFAO (Le Caire, 1969), p. 92, pl. XX, p. 84/1.

182) El-Weshahy, M., op. cit. (Fayoum, 2002), p. 47, fig. 5.

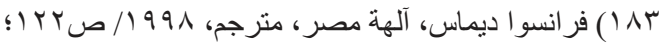

Kàksay, L., "Krokodilkult", L̈̈ III (1980), 803f.; Sauneron, S., Le Temple D'Esna, Tom V (1962), p.115.

184) Bonnet, H., Z̈̈S 75 (1939), 41, 45, 47f.; Book of Amy-Duat, 1,188, No. 803.

185) Sauneron, S., op. cit., Tom III, p. 263-265, Doc. 331.

186) Petrie, W. F., Gardiner, E., Naukratis, 1 (1886), p. 32, 40, 41,38.

187) Ashraf Abdel-Raouf, "Bronz Hoard from Heraclion", Seminar of the Archaeological Society of Alexandria (9-10 April 2003), Abstracts, p. 10

188) Gardiner, E., Naukratis, II (London, 1888), p!. XV, No. 14; Gwyn Griffiths, J., "Osiris and The Moon in Iconography", JEA 62 (1976), p. 156, pl. XVIII-3.

189) Yoyotte, J., MINERVA, Vol. 13/3 (2002), p. 34, fig. 6.

190) Gardiner, E., Egypt of the Pharaohs (New York. 1961), p. 393, 394, pi. XIX; Saleh, M., Saurouzian, H., Official Catalogue, The Egyptian Museum (Cairo, 1987), No. 7; Emry, W. B., Archaic Egypt (1991), p. 74.

191) Radwan, A., "Narmer, The Father of The Egyptian Civilization", A lecture during, "The Conference of the Centennial Celebrations of the Egyptian Museum ", December 2002.

192) El-sayed, R., op. cit., BdE 86/11 (1982), Doc. 457, 486, 515, 65, 666, 670;

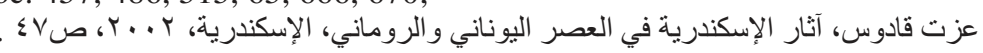

193) Yoyotte, J., MINERVA. Vol. 13/3 (2002), p. 34; El-Sayed, R., op. cit. (1982), Doc. 647, p. 485 (The Temple of Ptolemy II at Naukratis). 
194) Simon, C, "Neith", The Oxford Encyclopedia of Ancient Egypt, Vol. II (2001), p. 516; Spcnce, L., Ancient Egypt Myths and Legends (1990), p. 93, 95; Brovarski, E., "Two Writing Boards", ASAE 71 (1987), p.35; Kees, H., Ancient Egypt, A cultural Topography (Chicago, 1961), p. 185.

195) Grimal, N., op. cit. (1993), p. 457; Gardiner, E, op. cit. (1961), p. 364; El-Sayed, R., op. cit., I (1982), p. 164; II, Doc. 647, p. 480-n. 2.

196) Černý, J., Ancient Egyptian religion (1957), p. 124.

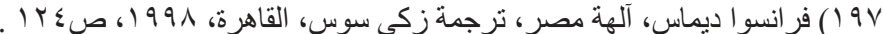

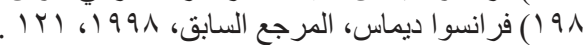

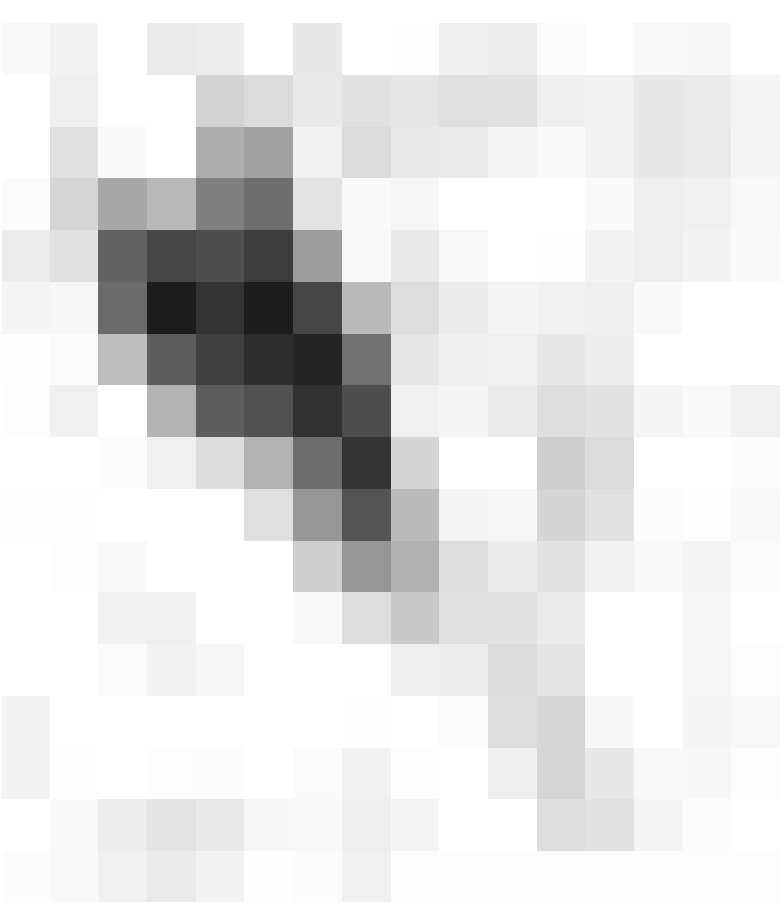

Fig. 1: The Bolbitine and Canopic Branches of the Nile Grimal, N, Histoire (1993), fig. 154

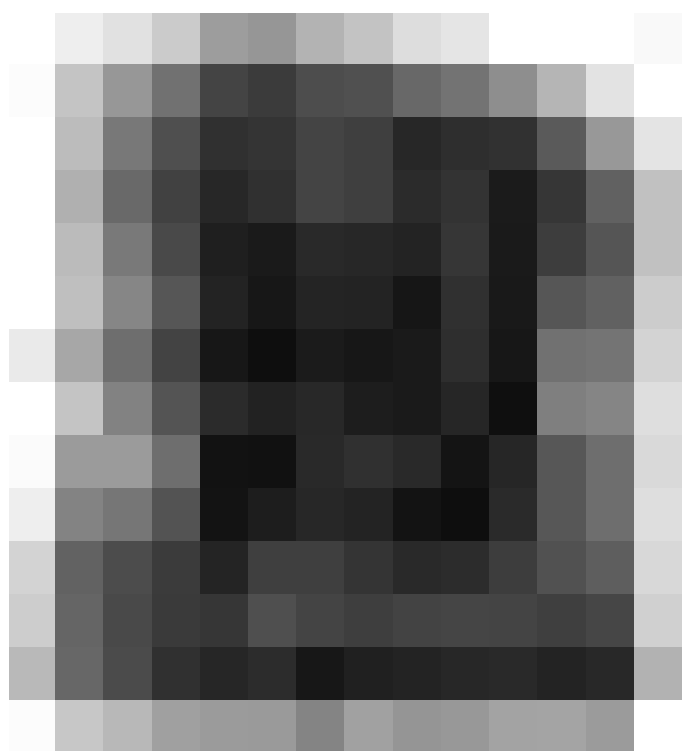

Fig. 3: Small objects from Naukratis Petrie, W. F., Scarabs (1917), pl. LVI, 6.5.4.2.

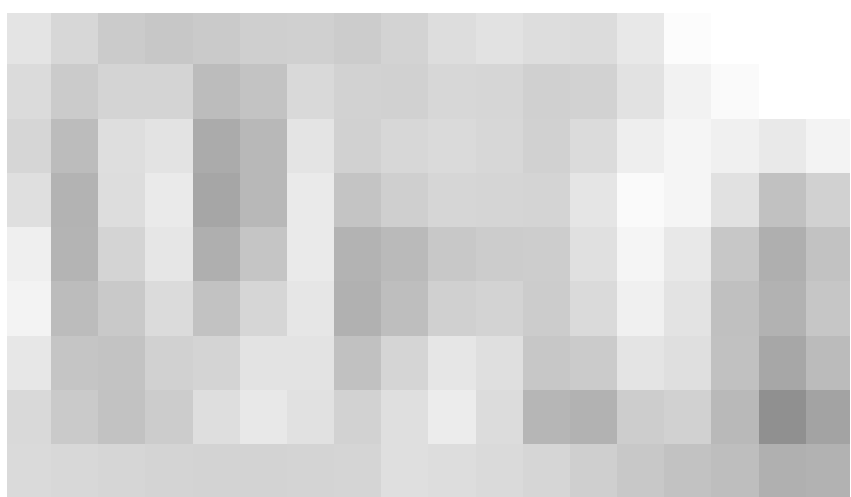

Fig. 2: Njt wrt at Fayoum Lanzone, Lac Mories (1896), Tav. V.

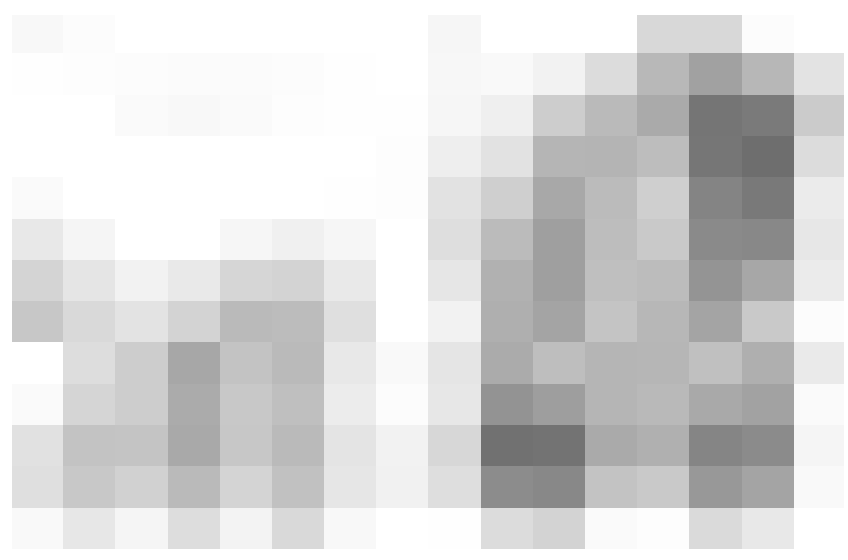

Fig. 4: Naos of the goddess Neith from Damanhur Roeder, G., Naos (1914), pl. XVI 


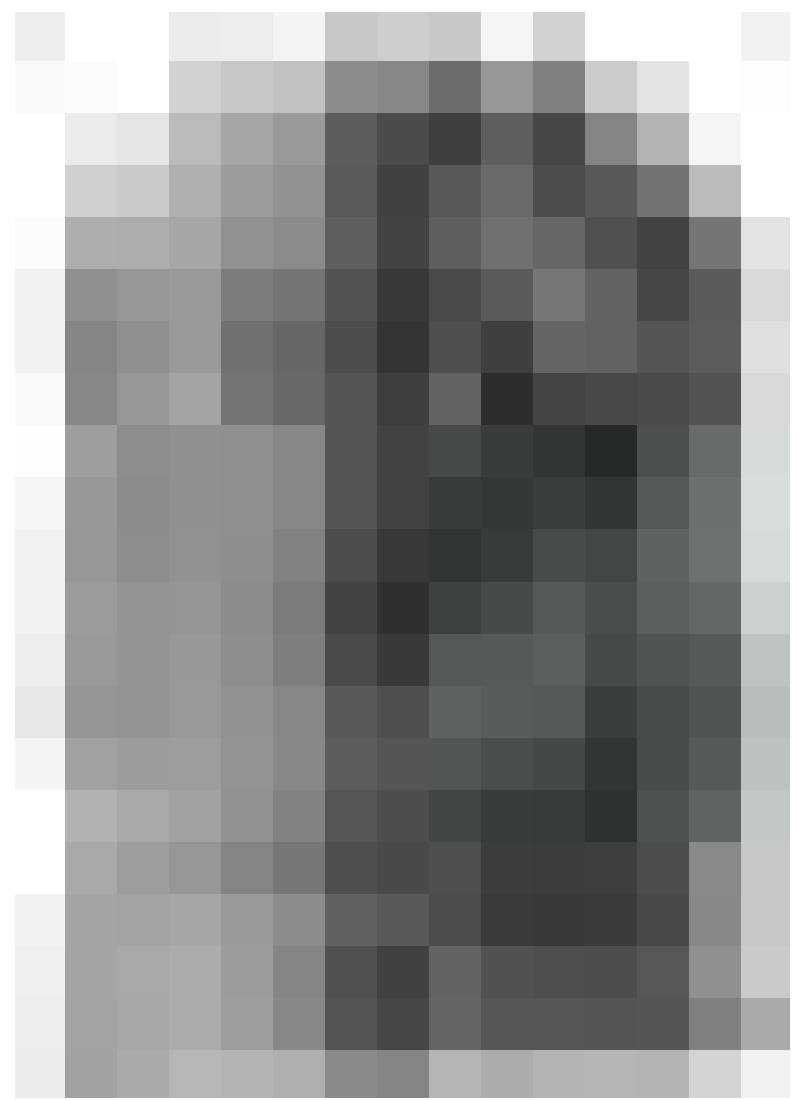

Fig. 5: Naukratis stela of goddess Neith Maspero, G.. Musee du Caire (1914), pl. IX

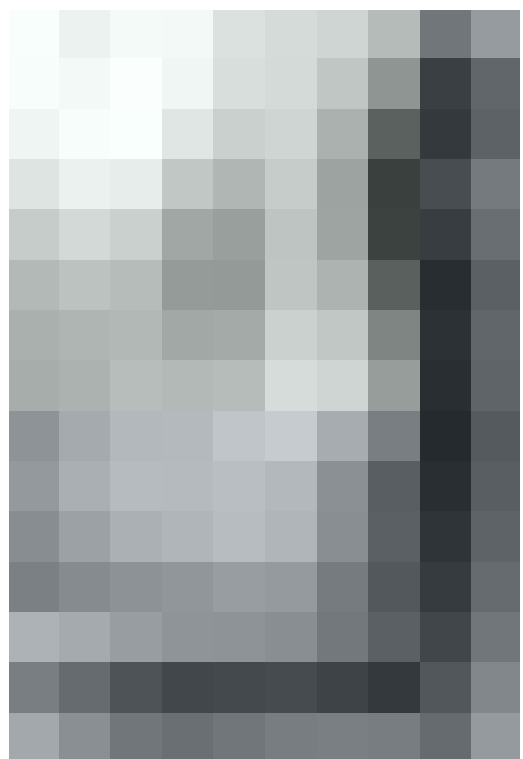

Fig. 7: The back pillar Bothmer, B. Von, ESLP (1960), No. 78.

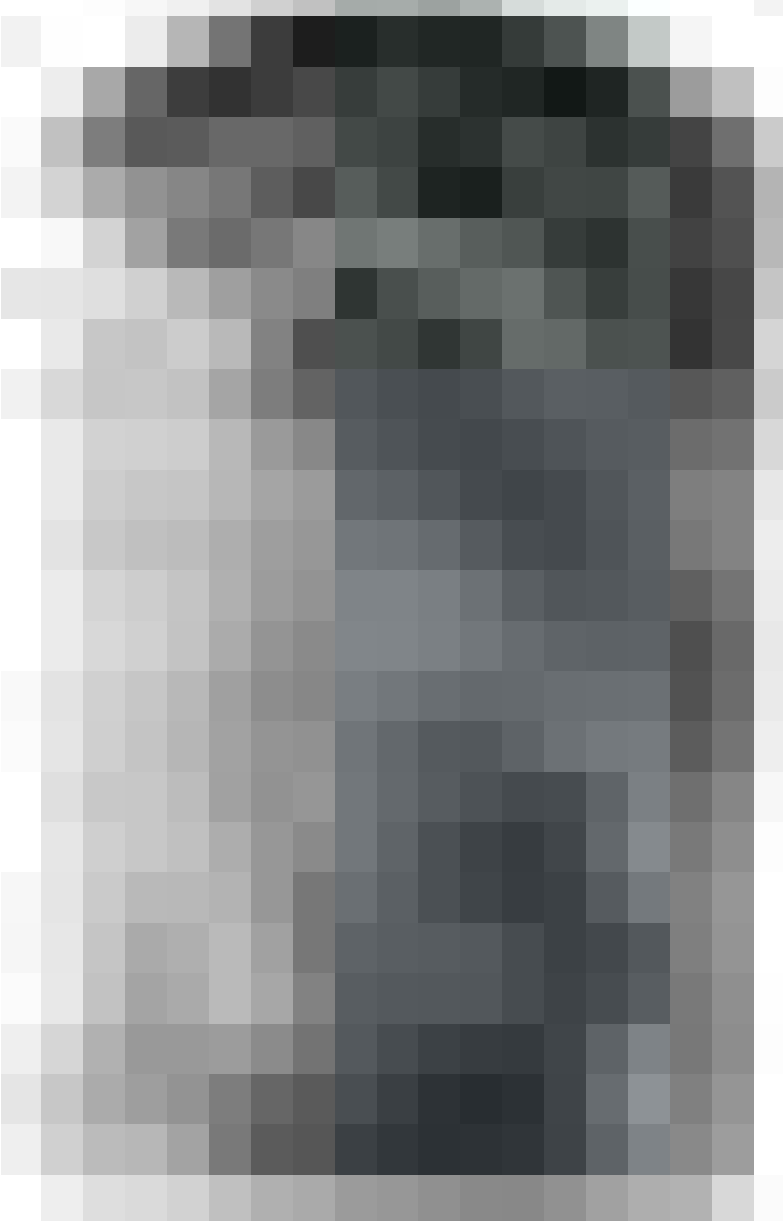

Fig. 6: Heracleion stela of goddess Nieth مهاة من أ./ أشرف عبد الرؤوف - إدارة الآثار الغارقة

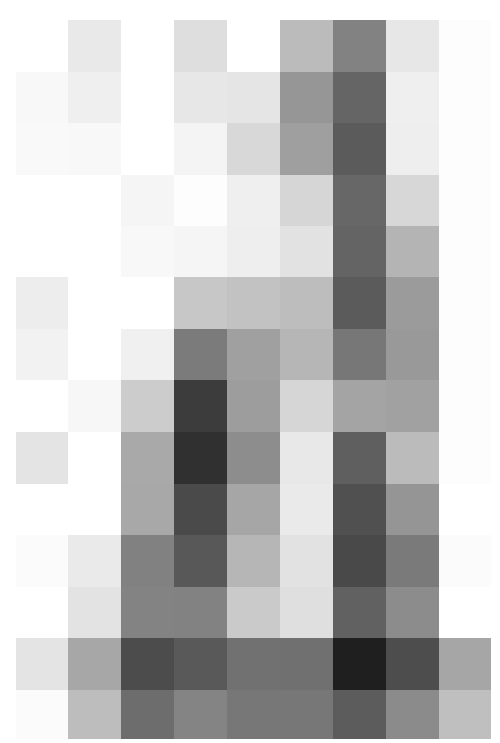

Fig. 8: Nieth with her children Louvre Museum 
Fig. 9: Head of sacred bark from Kom Afrin Petrie, W. F., Naukratis, I (1886), pl. XII

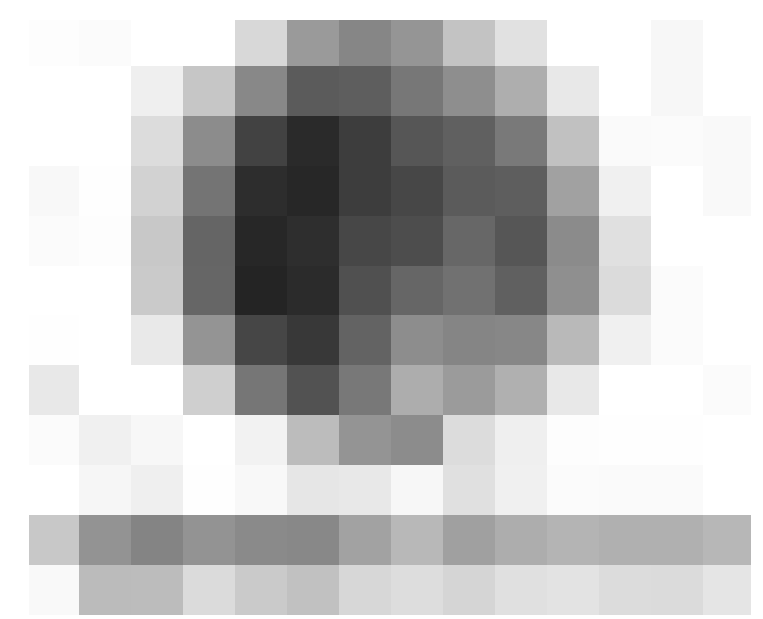

Fig. 11: Libation dish from Damanhur, Dyn. 26 Anderson, R., Description De L'Egypte (1987), pl. 74
Fig. 10: Plan of Ibis catacomb at Abu-Quir El-Quader, A. M., $\underline{A S A E} 56$ (1987), p. 123

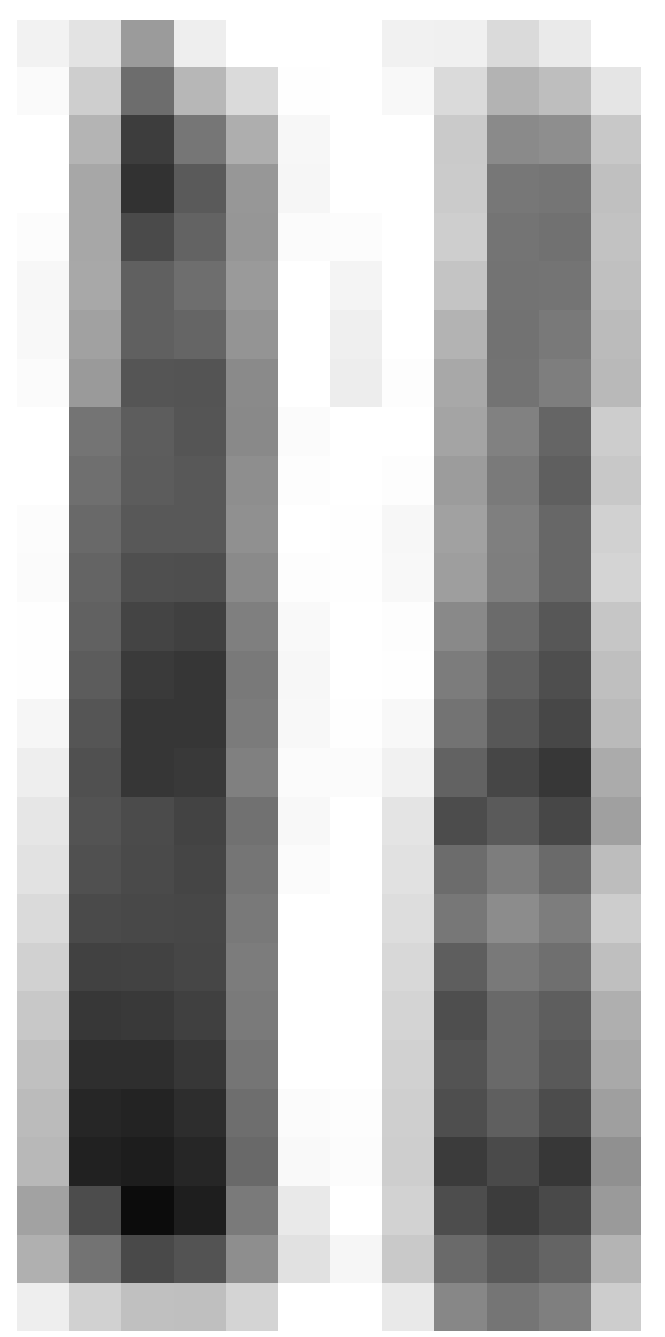

Fig. 12: Nectanebo II's obelisk from Damanhur Anderson, R., (1987), pl. 21, 22 


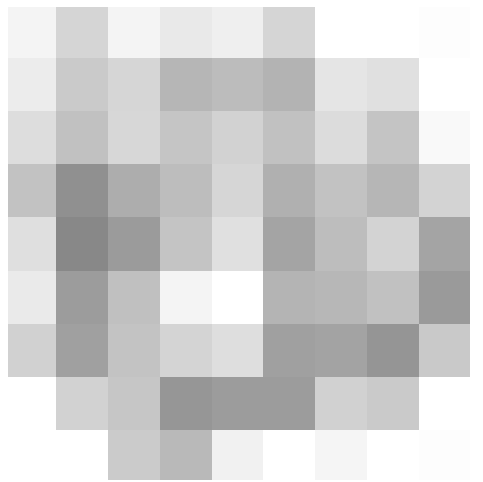

Fig. 13: The god Thoth Petrie, W. F., Naukratis, I, pl. XX-4

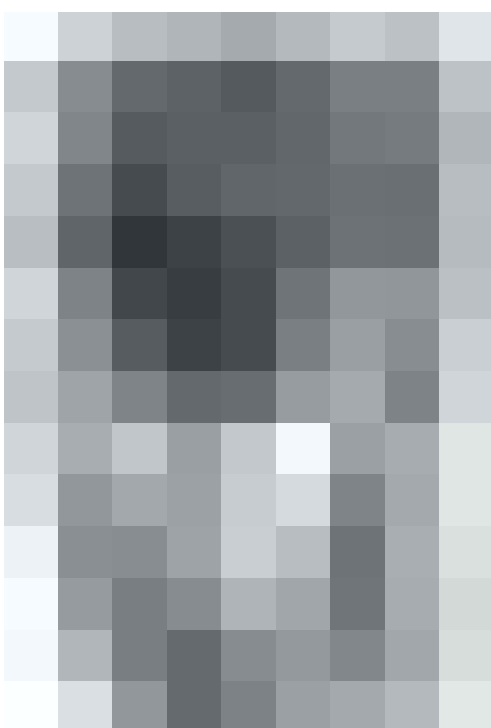

Fig. 14: Fragment of Damanhur Anderson, R., op. cit., pl. 73 $(13,14)$

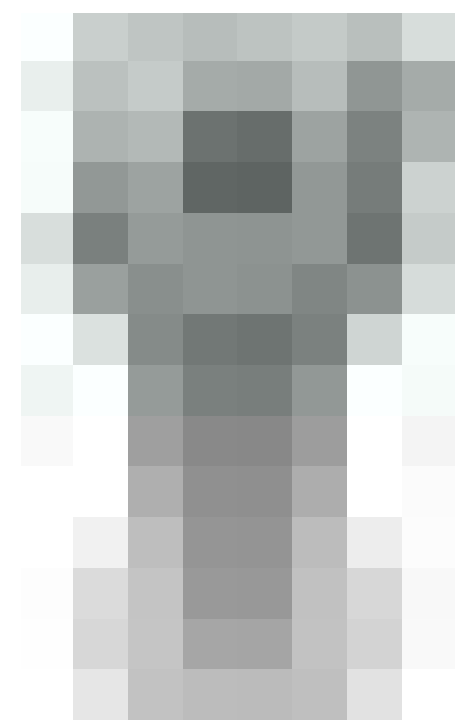

Fig. 15: Menat of Sekhmet Petrie, R., Naukratis, 1, pl. XX-8

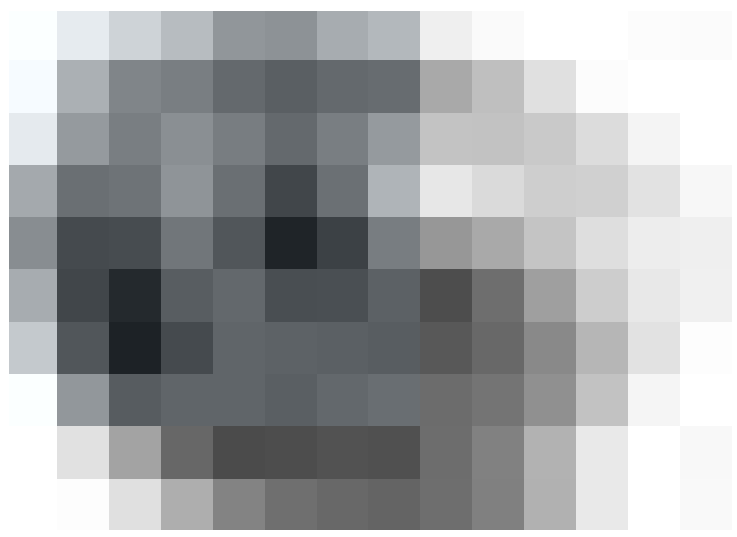

Fig. 16-a: Hedgehog lamp from Naukratis James, T., History (1995), p. 57
Fig. 16-b: Sekhmet as a hedgehog Davies, N. de G., Hibis (1953), pl. 5 (IV) 


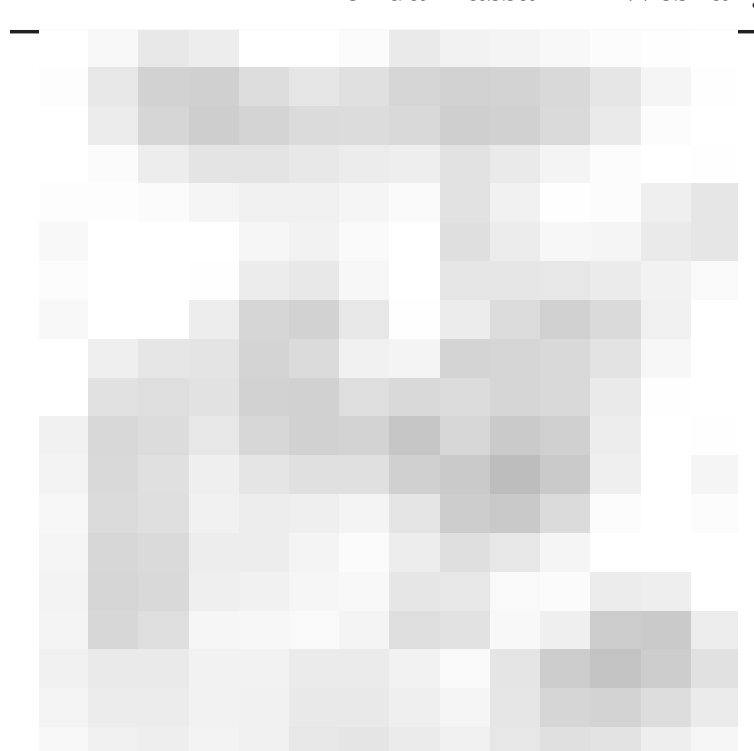

Fig. 17: The cow goddess Njt-ihjt El-Sayed, R., BdE 86/11 (1982), pl. X, Doc. 644

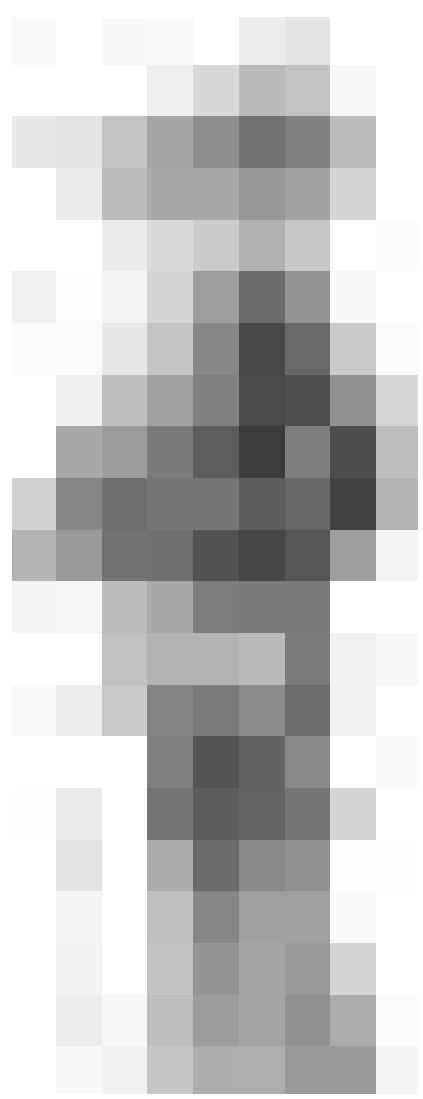

Fig. 19: Osiris as a moon-god from Naukratis Gwyn Griffiths, J., JEA 62 (1976), pl.XV1I1-3

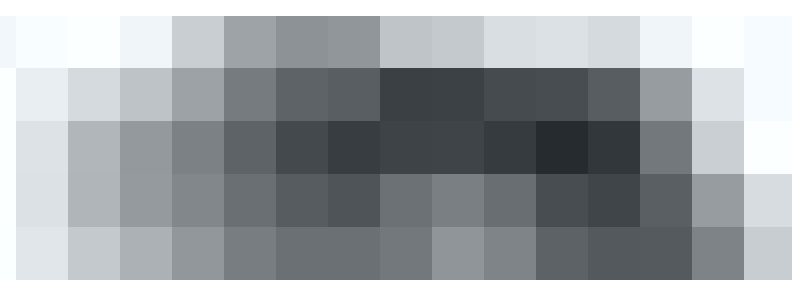

Fig. 18: Sobek from Naukratis, JE. 26764 Wild, H., Qasr-Qarun (1969), pl. XX

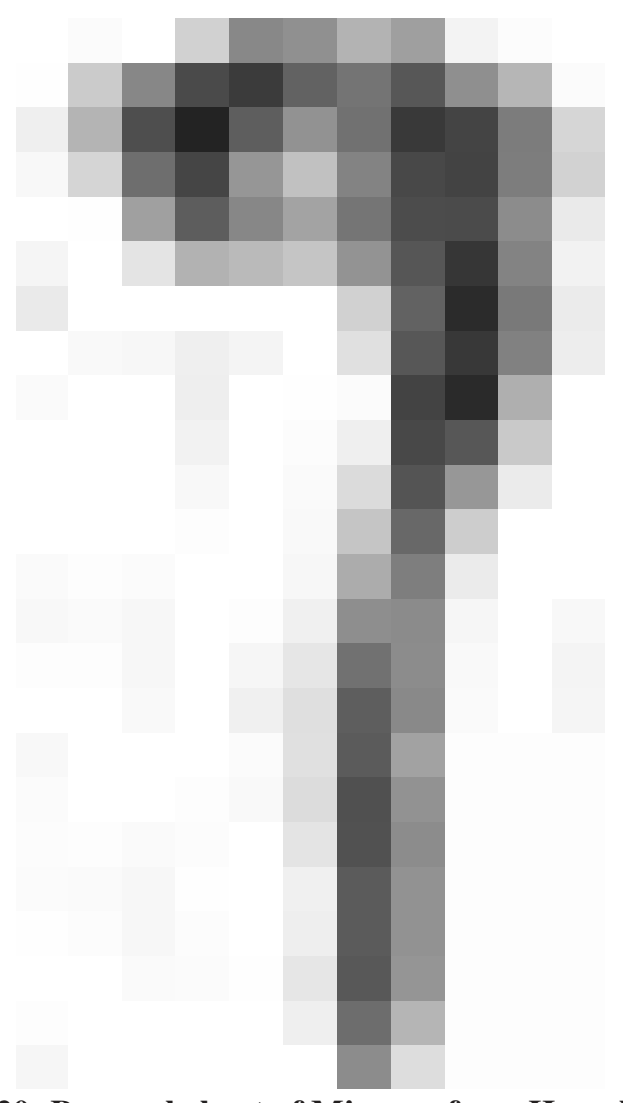

Fig. 20: Bronze helmet of Minerva from Heracleion Yoyotte, J., MINERVA, Vol. 13/3 (2002), fig.6

$$
\text { العلاقة بين الآلهة الرئيسية في إقليم البحيرة والإلهة نيت خلال العصر المتأخر }
$$

يتناول هذا البحث العلاقة بين الالهة الرئيسية لمقاطعة البحيرة والإلهة نيت خلال العصر المتأخر. فالإلهة نيت هى خالق كل الالهة، فقد

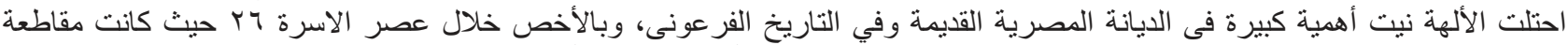

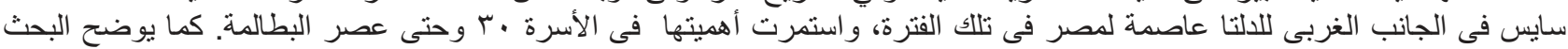
الصلة و العلاقة القوية بين الإلهة نيت وبين الآلهة و الآلهات المصرية القية القديمة في الدلتا. 